\title{
Comparing the incomparable? A review of methodical aspects in the sustainability assessment of wood in vehicles
}

\author{
Claudia Mair-Bauernfeind ${ }^{1}$ (i) $\cdot$ Martina Zimek ${ }^{1} \cdot$ Miriam Lettner $^{2} \cdot$ Franziska Hesser $^{3} \cdot$ Rupert J. Baumgartner ${ }^{1,4}$. \\ Tobias Stern ${ }^{1}$
}

Received: 15 July 2019 / Accepted: 28 July 2020 / Published online: 14 September 2020

(C) The Author(s) 2020

\begin{abstract}
Purpose The choice of materials used for a vehicle can contribute to reduce negative environmental and social impacts. Bio-based materials are considered a promising solution; however, the sustainability effects still need to be assessed. Depending on the material assessed, it is questionable which environmental and social impact categories or subcategories should be included since recommendations in guidelines are vague and case studies in this regard are limited. Therefore, this study aims to shed light on the choice of impact categories, methods, and indicators for E-LCA and S-LCA when assessing wood as substitute for conventional materials in automotive applications.

Method The research is based on a literature review covering 115 case studies of S-LCAs and E-LCAs focusing either on wood-based products or on components in automotive applications. The selected case studies were analyzed according to the following criteria: considered stakeholder groups and chosen subcategories (S-LCA sample), sector or product system (S-LCA sample), year of publication and geographical scope (S-LCA and E-LCA sample), chosen LCIA method(s) and impact categories, objective(s) of the studies, analyzed materials and used software support (E-LCA samples).

Results and discussion For S-LCA some relevant social topics for bio-based product systems, like food security or land- and worker-related concerns, could be identified. The E-LCA literature suggests that the objective and material type determine calculation approaches and impact category choices. Some material-related environmental issues like biodiversity loss in the case of bio-based product systems or ecotoxicity for steel and toxicity in the case of aluminum could be identified. For S-LCA the geographical and sectorial context and the affected stakeholders are the determining factors for methodical choices, however, the results show almost no difference in subcategory choice and geographical context. Influencing factors for methodical choices in E-LCA might be the objective of the study, data availability, the up-to-dateness of the LCIA approach, the geographical scope of the study, the materials analyzed, and the availability of software support.

Conclusion Some relevant environmental and social impact categories as well as influencing factors on methodical choices could be identified from existing literature. However, a clear picture on these issues could not be drawn. Further research is needed on the motivation of researches on certain methodical choices as well as on environmental issues connected with materials or geographical-related social topics.
\end{abstract}

Keywords E-LCA $\cdot$ S-LCA $\cdot$ Wood $\cdot$ Automotive $\cdot$ Impact category $\cdot$ Subcategory

Editorial Responsibility -Handling Editor: Jörg Schweinle

Claudia Mair-Bauernfeind

claudia.mair@uni-graz.at

1 Institute of Systems Sciences, Innovation and Sustainability Research, University of Graz, Merangasse 18, 8010 Graz, Austria

2 University of Applied Sciences Kufstein Tyrol, Andreas-Hofer-Straße 7, 6330 Kufstein, Austria
3 Wood K Plus, Competence Center for Wood Composites and Wood Chemistry, Kompetenzzentrum Holz GmbH, Altenberger Straße 69, 4040 Linz, Austria

4 Christian-Doppler-Laboratory for Sustainable Product Management enabling a Circular Economy, Merangasse 18, 8010 Graz, Austria 


\section{Introduction}

The automotive industry is confronted with increasing environmental and social requirements. Those challenges are posed by growing social and environmental awareness in the society and the recognition that sustainability is one driver for innovation (Ribeiro et al. 2007). Weight reduction through lightweight design has become an important lever in the automotive industry to decrease use-phase emissions (Delogu et al. 2017). Hence, the choice of materials used for a vehicle can contribute to reduce negative environmental and social impacts. Bio-based materials are considered a promising solution, because depending on the component and the system under study, using wood as a substitute for other materials has the potential to reduce the environmental impacts (e.g., less energy intensive than metals and plastics or less embodied impacts for acidification, climate change, and eutrophication) (Cordella and Hidalgo 2016; Petersen and Solberg 2005; Spitzley et al. 2006). Additionally, wood-based product systems are expected to contribute to social benefits, like an increase in local/rural employment and an improvement of infrastructure (Siebert et al. 2018b). Additionally, Touceda et al. (2018) mention that a substitution with wood can lead to improvements in supply chains like reducing the risk of injuries and fatalities.

The first vehicles were entirely made out of wood like the 1909 Ford Model T (Brooke 2008). Today, a typical passenger vehicle is composed of many materials, but wood is usually not part of a vehicle anymore (Mayyas et al. 2012a; Omar 2011). In recent years, the idea of bringing wood-based materials back into automotive applications has gained some attention again and was studied by several research projects (e.g., HAMMER or WoodC.A.R. ${ }^{1}$ ) focusing mostly on the technical feasibility but also on potential environmental and social impacts of material substitution or tradeoffs such as the opportunity of regional job creation at the cost of increasing risk of forced labor or increasing GHG emissions (Asada et al. 2020). Accepted methods to assess the potential environmental and social impacts are Environmental Life Cycle Assessment (E-LCA) or Social Life Cycle Assessment (S-LCA) (Benoît et al. 2010; Finnveden et al. 2009; Kloepffer 2008).

S-LCA aims to assess the potential positive and negative social and socioeconomic impacts of products along their life cycle (Dreyer et al. 2010a; Garrido 2017; UNEP/SETAC 2009). One of the most crucial steps in S-LCA is the selection of relevant indicators and impact categories. Impact categories and subcategories are different topics, which are of social relevance and "are the basis of a S-LCA assessment because they are the items on which justification of inclusion or

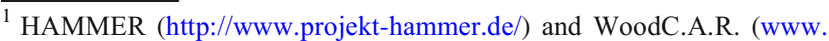
woodcar.eu)
}

exclusion needs to be provided" (UNEP/SETAC 2009, p. 44). When deciding for impact categories, a prioritization of the most relevant categories is challenging due to a lack of previous experience and knowledge (UNEP/SETAC 2009). Although there is a growing interest in S-LCAs in general and in S-LCAs for bio-based product systems, there are few recommendations available on how to decide for impact categories and relevant indicators for assessing bio-based product systems (Hasenheit et al. 2016; Rafiaani et al. 2018; Siebert et al. 2018a; Touceda et al. 2018). The lack of S-LCAs of the respective areas as well as the fact that those are still in its infancy (Petti et al. 2018) makes the identification of relevant social aspects challenging. Some guidance on S-LCA is provided by the UNEP/SETAC guidelines, where a general framework for conducting a study is proposed (Chen and Holden 2017; UNEP/SETAC 2009).

E-LCA aims to assess the environmental impacts of products and services along their life cycle from cradle to grave (ISO 2006a). As it is the case in S-LCA, E-LCA also requires as a first step the definition of the system under study. One aspect hereby is to identify which environmental issues (EC 2010c; ISO 2006a) and respectively which social topics and indicators (UNEP/SETAC 2009) are relevant for the system and should be covered in the analysis. In E-LCA the number and variety of indicators and LCIA methods available makes it difficult to choose the appropriate ones for a certain system under study (Finnveden et al. 2009; Rosenbaum et al. 2018). Understanding the main characteristics of a method and indicator as well as staying up-to-date with the developments in LCIA can be complex and time-consuming (Rosenbaum et al. 2018). Nevertheless, the choice of a LCIA method can be decisive for the outcome of the study, as well as calculating one impact category with different LCIA methods can lead to different results (Dreyer et al. 2003; Höglmeier et al. 2016; Owsianiak et al. 2014; Pizzol et al. 2011). The ISO standards 14040/14044 (2006a, 2006b) recommend to apply internationally accepted models and factors; however, Hauschild et al. (2013) state that none of the existing LCIA methods are accepted like the ISO standards call for. Because every system under study is unique, the recommendations from the ILCD handbook (EC 2010c) or the ISO standard 14040/14044 (ISO 2006a; 2006b) regarding indicators or methods are vague, which leads to rather loose guidance for LCA practitioners. One common recommendation is to include all main relevant environmental issues related to the system under study (EC 2010c; ISO 2006a) without giving criteria for how to rate the relevancy. In the ISO 14044 (2006b), it is stated that the choice of impact categories, category indicators, and characterization models should be consistent with the goal and scope of the study. Additionally, the choice depends on the environmental issues to be covered, the geographical context of the study (including mid- or endpoint assessment), and the interpretability and 
documentation as well as the up-to-dateness of the method (Rosenbaum et al. 2018).

Besides the recommendations provided by the UNEP/ SETAC guidelines ( 2009) for S-LCA and the ISO standards ( 2006a, 2006b) or the ILCD handbook (EC 2010b) for E-LCA, inputs on relevant social as well as environmental issues can be identified by referring to previous literature with similar research focus (Höglmeier et al. 2016). Unfortunately, just a limited number of E-LCA and S-LCA case studies for wood in automotive applications are available. Just a single study was found assessing the environmental impacts of an engineered wood product in an automotive application (Kohl et al. 2016). However, the authors did not consider the whole life cycle of the component compared with a functional equivalent nor the social effects of the component. No S-LCA case study of wood-based components in the automotive industry is currently available.

Therefore, the aim of this study is to shed light on the choice of impact categories, methods, and indicators for E-LCA and S-LCA when assessing wood as substitute for conventional materials in automotive applications. More precisely the aim is to answer the following research questions. RQ 1: Which environmental and social impact categories or subcategories are considered as relevant when assessing wood as a substitute for steel, aluminum, or composites in automotive applications? RQ 2: Which factors shape methodical choices (e.g., methods or indicators) in environmental and social LCA?

\section{Method and material}

In order to identify potential social topics and environmental issues as well as influencing factors for the choice of indicators, impact categories, and methods, an analytical approach is proposed by using a literature review. A research literature review can be defined as "a systematic, explicit, and reproducible method for identifying, evaluating, synthesizing the existing body of completed and recorded work produced by researchers, scholars, and practitioners" (Fink 2020, p. 6). Literature reviews usually reprocess the current state of research by aiming to provide a summary of themes and issues in a specific field or to identify the theoretical content within the analyzed research field (Engert et al. 2016; Meredith 1993). The approach applied for the present thesis is an interpretative content analysis, which, according to Neuendorf (2017), involves the theoretical sampling, the definition of analytical categories, the cumulative and comparative analysis of literature, as well as the formulation of types or conceptual categories.

To collect relevant E-LCA and S-LCA case studies for answering the research questions, a literature search was performed using the Scopus database, which comprises an adequate amount of scientific papers and journals (Klein et al. 2015). The examined study period was between 1990 and July 2018. The starting year of 1990 for the present study is adequate since the E-LCA literature started to emerge at this time (Zimek et al. 2019) and S-LCA later than the E-LCA literature. To identify the most relevant case studies, the literature research was limited to peer-reviewed articles and primary studies in English. Gray literature was excluded, as mentioned by Petti et al. (2018) within gray literature, a quality control is difficult and a higher quality is given in peer-reviewed studies. In the case of S-LCA, only a limited number of case studies focusing on bio-based product systems, wood-based products, or on components in automotive applications are available. However, the sector or industry specific as well as the geographical context is very important in S-LCA, as - dependent on the product system there can be important differences within one sector in a country (Dreyer et al. 2006; Jørgensen 2013; Siebert et al. 2018a; Siebert et al. 2018b). Consequently, other case studies besides studies focusing on wood-based and automotive product systems can provide important insights on sector as well as geographic dependent indicators. Therefore, the scope of literature was broadened to include all S-LCA case studies available on Scopus. To collect all those case studies, essential descriptors (keywords) of the examined subjects were chosen: "S-LCA" or "SLCA" or "Social Life Cycle Assessment" or "Social Life Cycle Analysis" and "case study" (present in Article title, Abstract, Keywords). In total 104 S-LCA case studies were identified. However, in this study, publications were analyzed specifically in which a geographical context and sector or product system was indicated since this is seen as essential in S-LCA (Dreyer et al. 2006; Jørgensen 2013; Siebert et al. 2018a; Siebert et al. 2018b). The UNEP/SETAC (2009) provide the general framework for conducting a S-LCA; wherefore, only those case studies are included, in which one or more of the 31 subcategories of the UNEP/SETAC guideline are included, or the chosen impact categories were assignable to the 31 subcategories of the UNEP/SETAC guideline (e.g., "job creation" is assignable to "local employment"). This resulted in 50 case studies for further analysis (see Fig. 1).

Again, just a limited number of E-LCAs with the particular focus of wood for automotive applications are available. However, studies focusing either on assessing wood-based products or on components in automotive applications can provide important insights on the considered environmental issues and impact categories, the chosen LCIA approach, as well as to identify possible methodological differences when assessing the environmental performance of different materials (bio-based and non-bio-based). Therefore, two different 
Fig. 1 Identified number of relevant case studies

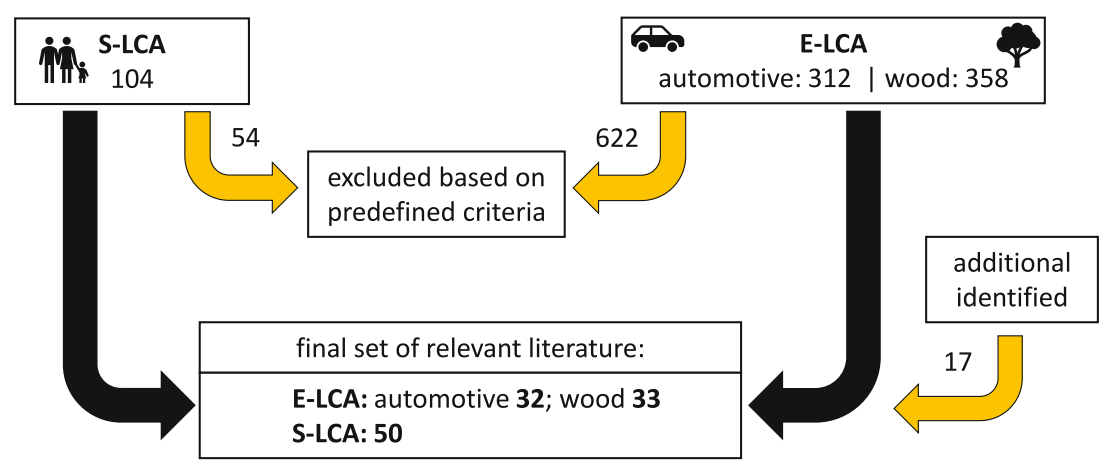

sets of literature were analyzed: E-LCAs of materials and components in automotive applications and E-LCAs of wood-based products. To identify relevant case studies focusing on assessing wood products, the keywords "Life Cycle Assessment" or "LCA" and "wood" and "product" or "component" or "part" (358) were used for the search. In the case of E-LCAs focusing on automotive components, the search string "Life Cycle Assessment" or "LCA" and "automotive" or "car" or "automobile" was applied which resulted in over 1000 publications. Many of those publications were out of scope and focused on, e.g., unmanned aerial vehicles, spacecrafts, underwater vehicles, planetary robotic rovers or rail, or air vehicles. After trying several additional keywords to limit the results to the most relevant for the present study, the following were found to be the most sufficient: "component" or "material" or "part" or "light*weight" (312). Hereby, those studies that actually focused on components in automotive vehicles and not on the complete vehicle as well as on material substitution effects were identified. The keyword "light*weight" was included because after screening through the titles after the first search, it became clear that one motivation for carrying out LCAs focusing on effects of material substitution was to identify sustainable lightweight solutions for the automotive industry.

In total this search resulted in 670 studies (Fig. 1) were several studies are still out of the scope for the present literature review. Therefore, the sample was limited according to the following criteria:

- Where a comparative E-LCA case study was performed

- Where the LCIA methods and/or impact categories were explained

- Where the focus of the case study was on assessing the impacts of solid wood or engineered wood products or wood-based products/materials and not on biofuel or construction

- Where the focus of the case study was on assessing the impacts of components or materials for automotive applications

- Where the focus was on assessing scenarios in order to identify potential benefits of lightweighting
After limiting the number of publications according to the previous listed criteria, a snowballing approach was used to identify additional relevant case studies. Using a snowballing approach means to screen the reference list of a paper or citations to the paper to gather additional relevant literature (Wohlin 2014). In the present study, the references of the papers included in the intermediate literature sample were screened in order to identify additional relevant E-LCA case studies (eight automotive and nine wood LCAs were added to the sample) (Fig. 1).

A qualitative content analysis as described by Neuendorf (2017) of the identified sample was performed by using the software MAXQDA (VERBI GmbH 2019). This method has been chosen as a huge amount of texts can be analyzed in a systematic way. Also, the method is not limited to any specific discipline and supports the researcher in interpreting the content of texts through a coding process (Hsieh and Shannon 2005; Mayring 2000). This was done to identify the factors influencing the choice of indicators as well as subcategories in S-LCA and respectively LCIA methods and impact categories in E-LCA (RQ2). The software was used to code each publication according to the following criteria: considered stakeholder groups and chosen subcategories (S-LCA sample), sector or product system (S-LCA sample), year of publication and geographical scope (S-LCA and E-LCA sample), chosen LCIA method(s) and impact categories, objective(s) of the studies, analyzed materials and used software support (E-LCA samples). The coded text was then analyzed step by step for each criterion to gain relevant information to answer the research questions. In the following chapters, the results of the literature and content analysis are presented. The results are spilt into two sections, one for S-LCA and the second for E-LCA. In each section, a brief insight into the respective method is provided, followed by the results on the relevant environmental and social impact categories or subcategories (RQ1). The last subchapter in the two sections presents the results regarding the influencing factors shaping the choice of methods and indicators in S-LCA and E-LCA (RQ2). 


\section{Results}

\subsection{Social life cycle assessment}

The UNEP/SETAC guidelines provide a general framework for conducting a S-LCA, where 31 subcategories are being suggested as the basis of a S-LCA (Chen and Holden 2017; UNEP/SETAC 2009). These subcategories are classified into five stakeholder groups (workers, local community, society, consumers, and value chain actors) and impact categories (UNEP/SETAC 2009) (Fig. 2). Although the UNEP/SETAC provide a general framework for conduction an S-LCA, several authors point out that S-LCA is still under development, faces several (methodological) challenges, and lacks empirical studies (Arcese et al. 2018; Baumann et al. 2013; Benoît et al. 2010; Kühnen and Hahn 2017; Salazar et al. 2012; Sureau et al. 2018).

The product or sector/industry and company-specific social impacts highly influence different stakeholders and stakeholder groups (Dreyer et al. 2006). Especially workers and labor conditions gained increasing interest in the S-LCA literature. Labor rights was the focus of Dreyer et al. (2010a), and within their so-called contextual risk classes (CRC), they assessed child labor, forced labor, discrimination, and restrictions of freedom of association (Dreyer et al. 2010b). Additionally, the geographical context and the industry of the companies along the whole supply chain are important since, for instance, the social impacts of an ore mine in Brazil might be completely different compared with the impacts of a sawmill in Austria (Benoît et al. 2010; Dreyer et al. 2010a; Jørgensen 2013).

\subsubsection{Social issues for automotive and bio-based product systems}

While there is currently no S-LCA case study of wood components in the automotive industry available, there are some studies available that deal with social impacts in the automotive industry (Traverso et al. 2018; Zimmer et al. 2017) or of wood-based products (Siebert et al. 2018a; Siebert et al. 2018b; Touceda et al. 2018) or the social impacts of the bioeconomy (Hasenheit et al. 2016; Rafiaani et al. 2018). A bioeconomy is seen as an economy where the basic components of materials, chemicals, and energy are made out of biobased resources (McCormick and Kautto 2013). This means a bioeconomy focuses on bio-based products and bio-based product systems; wherefore, the studies of Hasenheit et al. (2016) and Rafiaani et al. (2018) are considered as relevant in identifying social issues of bio-based product systems.

Regarding the social issues of automotive product systems, Zimmer et al. (2017) assessed the social risks of global supply chains and demonstrated different options of analysis for a case of a premium car manufacturer. They point out that not only the choice of the right indicators but also the weighting of indicators (e.g., together with different stakeholders) is of great importance for assessing social risks in supply chains (Zimmer et al. 2017). Traverso et al. (2018) identified 26 relevant indicators to assess the social impacts of a run on flat tire mounted on a BMW3 series. These indicators (e.g., health and safety, wages and social benefits, working hours, child labor, forced labor for workers; no details on the stakeholder groups other value chain actors and society) are split into
Fig. 2 Considered stakeholder groups and subcategories in SLCA recommended by the UNEP/SETAC ( 2009) guidelines for S-LCA

\begin{tabular}{|c|c|}
\hline Worker & Other value chain actors \\
\hline $\begin{array}{l}\text { - } \text { Freedom of association and collective } \\
\text { bargaining } \\
\text { - } \text { Child labor } \\
\text { - } \text { Fair salary } \\
\text { - } \text { Working hours } \\
\text { - } \text { Equality/ discrimination } \\
\text { - Health and safety } \\
\text { - } \quad \text { Social benefits and social security } \\
\end{array}$ & $\begin{array}{l}\text { - } \text { Respect for intellectual property rights } \\
\text { - } \text { Promoting corporate social responsibility } \\
\text { - Healthy competition } \\
\text { - } \text { Suppliers relations } \\
\text { - End-of-life } \\
\text { - } \text { Feedback mechanism }\end{array}$ \\
\hline \multicolumn{2}{|l|}{ Local Community } \\
\hline $\begin{array}{l}\text { - Access to material resources } \\
\text { - Access to immaterial resources } \\
\text { - Delocalization and migration } \\
\text { - Cultural heritage } \\
\text { - Safe and healthy living conditions }\end{array}$ & $\begin{array}{l}\text { - Indigenous people's rights } \\
\text { - Community engagement } \\
\text { - Local employment } \\
\text { - Secure living }\end{array}$ \\
\hline Society & Consumers \\
\hline $\begin{array}{l}\text { - Public commitment on sustainable } \\
\text { development issues } \\
\text { - Contribution to economic development } \\
\text { - Prevention and mediation of armed } \\
\text { conflict } \\
\text { - Corruption } \\
\text { - Technological development } \\
\end{array}$ & $\begin{array}{l}\text { - } \text { Health and safety } \\
\text { - } \text { Feedback mechanism } \\
\text { - } \text { Consumer privacy } \\
\text { - } \text { Transparency } \\
\text { - } \quad \text { End-of-life responsibility }\end{array}$ \\
\hline
\end{tabular}


three stakeholder groups, namely, worker, customers, and local communities.

The social issues of bio-based product systems are analyzed; for instance by Hasenheit et al. (2016) who summarized possible social indicators to assess a biobased economy, e.g., the use of agrochemicals, malnutrition, or job quality (see Table 1). The review of Rafiaani et al. (2018) shows common social indicators within the bio-based economy, namely, health and safety, food security, income, employment, land- and worker-related concerns, energy security, profitability, and gender issues. Siebert et al. (2018a, 2018b) define appropriate and relevant indicators for a social assessment of wood-based products within a bioeconomy region in Germany (see Table 1). Another case study of Touceda et al. (2018) assesses the sustainability of a tailored development for housing retrofit. This study does not address a specific wood example. However, they propose wood as a substitute for metallic windows frames. An overview and summary of the social impact topics and possible indicators of these studies is given in Table 1 .

The identified social impacts as shown in Table 1 provide an overview of possible impacts of wood-based products and of a bioeconomy and, respectively, bio-based product systems. It has to be noted that each factor is somehow related to other factors, e.g., a change in prices possibly directly or indirectly affects food security in a region (Hasenheit et al. 2016).

\subsubsection{Factors influencing methodical choices in S-LCA}

The products or sectors assessed within the 50 identified S-LCA case studies range from textiles, sugarcane, car tires

Table 1 Overview of identified social impacts and indicators for assessing bio-based product systems, proposed by Hasenheit et al. (2016) [1], Rafiaani et al. (2018) [2], Siebert et al. (2018a) [3], and Touceda et al. (2018) [4]

\begin{tabular}{|c|c|c|}
\hline \multirow{2}{*}{$\begin{array}{l}\text { Social impact } \\
\text { Food security }\end{array}$} & \multicolumn{2}{|l|}{ Possible indicators } \\
\hline & $\begin{array}{l}\text { - Use of agrochemicals, fertilizers [1] } \\
\text { - Change in food prices, price volatility [1] }\end{array}$ & $\begin{array}{l}\text { - Malnutrition, risk of hunger [1] } \\
\text { - Macronutrient intake/availability [1] }\end{array}$ \\
\hline Land access & $\begin{array}{l}\text { - Land prices [1] } \\
\text { - Access to land (incl. gender equality) [1] }\end{array}$ & $\begin{array}{l}\text { - Land tenure [1] } \\
\text { - Property rights (incl. gender equality) [1] }\end{array}$ \\
\hline Employment & $\begin{array}{l}\text { - Change in employment rate [1] } \\
\text { - Job conditions (rate of qualified employees, rate of } \\
\text { marginally employed) [1], [3] } \\
\text { - Duration of employment (rate of fixed-term employees, } \\
\text { rate of employees provided by temporary work agencies) } \\
\text { [3] } \\
\text { - Full-time equivalent jobs [1] }\end{array}$ & $\begin{array}{l}\text { - Job quality [1] } \\
\text { - Need for/lack of highly specialized workforce [1] } \\
\text { - Working time (contractual working hours, compensation for } \\
\text { overtime) [3] } \\
\text { - Work-life-balance (access to flexible working time } \\
\quad \text { agreements, rate of part-time employees) [3] }\end{array}$ \\
\hline $\begin{array}{l}\text { Household income } \\
\text { /adequate remunera- } \\
\text { tion }\end{array}$ & $\begin{array}{l}\text { - Income of employees in bioeconomy sector (total) [1] } \\
\text { - Payment (payment according to basic wage, } \\
\text { average remuneration level) [3] }\end{array}$ & $\begin{array}{l}\text { - Distribution of income [1] } \\
\text { - Financial participation (capital participation, profit-sharing } \\
\text { and bonuses) [3] }\end{array}$ \\
\hline Quality of life & - Change of quality of life [1] & - Equality (of gender, etc.) [1] \\
\hline Health and safety & $\begin{array}{l}\text { - Exposure to agrochemicals [1] } \\
\text { - Numbers of multi-resistant organisms [1] } \\
\text { - Toxicity of "green" vs. "gray" industrial products [1], [3] } \\
\text { - Accidents (occupational (fatal) accidents) [1], [3] }\end{array}$ & $\begin{array}{l}\text { - Occupational diseases per working hour [4] } \\
\text { - Sick-leave (number of workdays lost per worker and year, } \\
\quad \text { sick-leave days, preventive health measures) }[1],[3]\end{array}$ \\
\hline Knowledge capital & $\begin{array}{l}\text { On-the-job training (employees participated in training, } \\
\text { support for professional qualification) [3] } \\
\text { Vocational training (rate of vocational trainees, } \\
\text { rate of vocational trainees hired) [3] }\end{array}$ & $\begin{array}{l}\text { - Research and development (rate of employees in research anc } \\
\text { development) [3] }\end{array}$ \\
\hline Participation & $\begin{array}{l}\text { - Workers participation (works' council, } \\
\text { other measures for participation) [3] }\end{array}$ & \\
\hline $\begin{array}{l}\text { Land- and worker-related } \\
\text { concerns }\end{array}$ & - No possible indicators proposed [2] & \\
\hline Energy security & - No possible indicators proposed [2] & \\
\hline Profitability & - No possible indicators proposed [2] & $\begin{array}{l}\text { - Investment and return (state) [4] } \\
\text { - Avoided costs (state) [4] }\end{array}$ \\
\hline $\begin{array}{l}\text { Equal } \\
\text { opportunities/gender } \\
\text { issues }\end{array}$ & $\begin{array}{l}\text { - No possible indicators proposed [2] } \\
\text { - Older employees (measures to support older employees) } \\
\text { [3] } \\
\text { - Minorities (rate of disabled employees, rate of foreign } \\
\text { employees) [3] }\end{array}$ & $\begin{array}{l}\text { - Gender equality (rate of female employees in management } \\
\text { positions, measures to improve gender equality) [3] }\end{array}$ \\
\hline Consumer issues & $\begin{array}{l}\text { - Indoor air quality [4] } \\
\text { - Adequate indoor temperature [4] }\end{array}$ & $\begin{array}{l}\text { - Fuel poverty gap (inability to afford keeping a home warm a } \\
\text { a reasonable price) [4] }\end{array}$ \\
\hline
\end{tabular}


to recycling systems or manufacturing companies (Table 3). Out of the 50 S-LCA case studies, seven case studies have been identified, which analyze bio-based product systems (e.g., Pizzirani et al. 2018; Siebert et al. 2018a or Agyekum et al. 2017), and one case study has been identified directly related to the automotive industry (Zimmer et al. 2017) (Table 3). These are the basis to identify possible relevant stakeholder groups, subcategories, and/or indicators.

The importance of a sector-specific and geographical context has already been mentioned in several papers in the past (e.g., Benoit et al. (2010) highlight the need of site-specific data; Dreyer et al. (2010a) conclude that the regional context and the industry itself highly influence the external risk environment). The geographical context might also influence the choice of indicators, e.g., in the USA the risk of child labor is considered to be lower compared with, e.g., India or countries with high poverty rates, whereas for other indicators, the opposite is the case (e.g., the risk of not having collective bargaining rights) (Arvidsson et al. 2015; Benoit-Norris et al. 2012). Because of the importance of the regional context in S-LCA (Dreyer et al. 2010a; Jørgensen 2013), it is reasonable to assume that stakeholder groups, subcategories, and/or indicators are chosen on the basis of the geographical context and country. Therefore, investigated countries in the case studies analyzed are split into developing and developed countries based on the United Nations (2014) (see also in Petti et al. 2018). The countries chosen in S-LCAs of bio-based product systems are highlighted with an asterisk in Table 2. The case study within the automotive industry has been conducted for Germany.

An overview of all considered S-LCAs is provided in Table 3, whereby the case studies are categorized by the topic (product system under study) and split up concerning the geographical context (developing and developed countries) (see Table 2).

Slightly more case studies are found for developing countries ( 29 vs 32 ), whereby several case studies are conducted for more than one country, including both developing and developed countries. The chosen product system, company, or sector is very heterogeneous in both groups. All 50 case studies were analyzed concerning the chosen subcategories based on UNEP/SETAC ( 2009) in relation to the geographical context, each split in developed and developing countries (see Fig. 3).

The results in Fig. 3 show that $57 \%$ of the 50 S-LCA case studies investigated subcategories concerning the stakeholder group worker and $25 \%$ investigated subcategories within the stakeholder group local community. Subcategories from the other three stakeholder groups (value chain actors, society and consumers) were examined in $18 \%$ of the considered studies.

Regarding the assumption that subcategories might be chosen depending on the geographical context or the economic status of countries (developed and developing countries), no big differences could be identified. The stakeholder groups value chain actors, society, local community, and worker are chosen more often when S-LCAs were conducted in developing countries (biggest differences for the stakeholder group worker). Only for the stakeholder group consumer, more S-LCA case studies are conducted in developed countries. As illustrated within Fig. 3 only six subcategories show slightly bigger differences between developing and developed countries, namely, child labor, fair salary, working hours and access to material resources are chosen more often in developing countries and forced labor, health and safety (consumer) and local employment are more often chosen in developed countries. Of the case studies which analyzed bio-based product systems (see Table 3), six refer to developing and four to developed countries. Within all studies, the subcategory "local employment" is chosen, followed by "health and safety" ( 9 studies) and 'fair salary' (8 studies). Additionally, more than half of the studies include "social benefits/social security," "equal opportunities/discrimination," "working hours," and "child labor" as subcategories.

\subsection{Environmental life cycle assessment}

E-LCA has developed to a widely acknowledged tool - used across various areas - for assessing the potential environmental impacts of a product or service system (Finnveden et al. 2009; Guinée et al. 2011; Zimek et al. 2019). It has been standardized within ISO14040/14044 (ISO 2006a, b) and defines four phases of an LCA study: goal and scope definition, life cycle inventory (LCI), life cycle impact assessment (LCIA), and the interpretation phase. In the LCI phase, the input/output data of the studied

Table 2 Overview of the chosen countries of the selected case studies split in developing and developed countries

\begin{tabular}{ll}
\hline $\begin{array}{l}\text { Geographical } \\
\text { context }\end{array}$ & Countries within the considered S-LCA case studies \\
\hline $\begin{array}{c}\text { Developed } \\
\text { countries }\end{array}$ & $\begin{array}{c}\text { Australia, Austria, Belgium, Canada*, Croatia, Denmark, Germany*, Greece, Hungary, Ireland, Italy, Japan, the Netherlands, } \\
\text { New Zealand*, Portugal, Spain, United States* } \\
\begin{array}{c}\text { Developing } \\
\text { countries }\end{array} \\
\text { Algeria, Angola, Argentina*, Bangladesh, Brazil*, China, Democratic Republic of Congo, East Timor, Ecuador, Equatorial Guinea, } \\
\text { Ghana*, India, Indonesia*, Iran*, Israel, Jordan, Kuwait, Malaysia*, Mexico, Mongolia, Morocco, Mozambique, Pakistan, Peru, } \\
\text { Rwanda, Sierra Leone, South Africa, South Korea, Taiwan, Thailand, Turkey, Zambia }\end{array}$ \\
\hline
\end{tabular}

*Countries chosen in S-LCAs of bio-based product systems 
Table 3 S-LCA case studies (product, sector, company) categorized by topic and geographical context (developing and developed countries); some studies are in both categories as some case studies relate to more countries

\begin{tabular}{|c|c|c|}
\hline Topic & Developed countries & Developing countries \\
\hline Agriculture & $\begin{array}{l}\text { Chen and Holden } 2017 \text { (dairy farm); Franze and Ciroth } 2011 \\
\text { (rose bouquets); Martínez-Blanco et al. } 2014 \text { (fertilizers); } \\
\text { Teah and Onuki } 2017 \text { (recycled P fertilizers) }\end{array}$ & $\begin{array}{l}\text { Franze and Ciroth } 2011 \text { (rose bouquets); Martínez-Blanco } \\
\text { et al. } 2014 \text { (fertilizers); Teah and Onuki } 2017 \\
\text { (recycled P fertilizers) }\end{array}$ \\
\hline $\begin{array}{l}\text { Apparel } \\
\text { industry }\end{array}$ & Lenzo et al. 2017 and Zamani et al. 2018 (textiles) & $\begin{array}{l}\text { Mair et al. } 2018 \text { (clothing supply chain); Zamani et al. } 2018 \\
\text { (textiles) }\end{array}$ \\
\hline $\begin{array}{l}\text { Automotive } \\
\text { industry }\end{array}$ & Zimmer et al. 2017 (automotive industry) & Zimmer et al. 2017 (automotive industry) \\
\hline $\begin{array}{r}\text { Bio-based } \\
\text { product } \\
\text { systems }\end{array}$ & $\begin{array}{l}\text { do Carmo et al. } 2017 \text { (biodiesel); Pizzirani et al. } 2018 \text { (radiata pine); } \\
\text { Siebert et al. } 2018 \text { a (wood-based products) }\end{array}$ & $\begin{array}{l}\text { do Carmo et al. } 2017 \text { (biodiesel); Agyekum et al. } 2017 \\
\text { (bamboo bicycle frames); Ghaderi et al. } 2018 \\
\text { (switchgrass-based bioethanol); Manik et al. } 2013 \text { (palm } \\
\text { oil biodiesel); Souza et al. } 2018 \text { (biorefinery scenarios) }\end{array}$ \\
\hline $\begin{array}{l}\text { Construction } \\
\text { (materials), } \\
\text { housing }\end{array}$ & $\begin{array}{l}\text { Arcese et al. } 2013 \text { (accommodation facilities), Touceda et al. } 2018 \\
\text { (housing retrofitting processes) }\end{array}$ & $\begin{array}{l}\text { Dong and Ng } 2015 \text { (public housing project); Dong and Ng } \\
2016 \text { (building construction project); Fan et al. } 2018 \\
\text { (green residential districts); Hossain et al. } 2018 \text { (recycled } \\
\text { construction materials); Hosseinijou et al. } 2014 \text { (building } \\
\text { materials, cement, and steel); } \\
\text { Singh and Gupta } 2018 \text { (steel) }\end{array}$ \\
\hline Energy sector & $\begin{array}{l}\text { Corona et al. } 2017 \text { (solar power plant); Traverso et al. } 2012 \\
\text { (photovoltaic (PV) modules); Tsalis et al. } 2017 \text { (energy companies); } \\
\text { Kolotzek et al. } 2018 \text { (capacitor technologies); Wulf et al. } 2017 \\
\text { (rare earth permanent magnet for use in wind turbines) }\end{array}$ & $\begin{array}{l}\text { Tseng et al. } 2017 \text { (wind power); Kolotzek et al. } 2018 \\
\text { (capacitor technologies); Wulf et al. } 2017 \\
\text { (rare earth permanent magnet for use in wind turbines) }\end{array}$ \\
\hline Food sector & $\begin{array}{l}\text { Neugebauer et al. } 2017 \text { (tomatoes); Andrews et al. } 2009 \text { (tomatoes); } \\
\text { Arcese et al. } 2017 \text { (wine); de Luca et al. } 2018 \text { (Calabrian olives); } \\
\text { Petti et al. 2018a (tomatoes); Sanchez Ramirez et al. } 2014 \text { (wine } \\
\text { company) }\end{array}$ & $\begin{array}{l}\text { Neugebauer et al. } 2017 \text { (tomatoes); Du et al. } 2018 \\
\text { (sugarcane); Prasara-A and Gheewala } 2018 \text { (sugar) }\end{array}$ \\
\hline $\begin{array}{l}\text { Waste } \\
\text { management }\end{array}$ & $\begin{array}{l}\text { Lehmann et al. } 2011 \text { (water resources management and integrated } \\
\text { packaging waste) }\end{array}$ & $\begin{array}{l}\text { Lehmann et al. } 2011 \text { (water resources management and } \\
\text { integrated packaging waste); Aleisa and Al-Jarallah } \\
2018 \text { (waste management system); Aparcana and } \\
\text { Salhofer } 2013 \text { (recycling systems); Mirdar Harijani et al. } \\
2017 \text { (municipal solid waste); Opher et al. } 2018 \text { (urban } \\
\text { domestic water reuse alternatives) }\end{array}$ \\
\hline others & $\begin{array}{l}\text { Reuter } 2016 \text { (lithium-ion batteries); Schau et al. } 2012 \text { (remanufactured } \\
\text { alternators); Dreyer et al. 2010b (manufacturing companies); Hannouf } \\
\text { and Assefa } 2018 \text { (high-density polyethylene, HDPE); Subramanian } \\
\text { et al. } 2018 \text { (nano-enabled biocidal paint) }\end{array}$ & $\begin{array}{l}\text { Reuter } 2016 \text { (lithium-ion batteries); Schau et al. } 2012 \\
\text { (remanufactured alternators); Dreyer et al. 2010a } \\
\text { (manufacturing companies); Sanchez Ramirez et al. } \\
2014 \text { (cocoa soap); Wang et al. } 2017 \text { (IC packaging) }\end{array}$ \\
\hline
\end{tabular}

system is collected and analyzed (ISO 2006a). The LCIA phase includes three mandatory elements: first, the selection of impact categories, category indicators, and characterization models; second, assigning inventory results to impact categories; and third, calculating the category indicator results (ISO 2006b). The calculation of LCIA can be done by using an LCIA method (Table 4), which combines a number of category indicators as well as calculates the results based on specific characterization models (Hauschild et al. 2013) and are partly implemented in LCA software (Rosenbaum et al. 2018). LCIA methods exist for midpoint level (CML 2002, EDIP, TRACI) and endpoint level (EPS, Eco-Indicator 99) as well as methods that try to combine the mid- and endpoint levels (LIME, ReCiPe, IMPACT 2002+) (EC 2010c; Hauschild et al. 2013; Pennington et al. 2004) (Table 4). On midpoint level, a higher number of impact categories are differentiated, and at endpoint level, the impacts are shown as effects on the areas of protection (human health, natural environment, natural resources) (EC 2010c; Pennington et al. 2004; Udo de Haes et al. 1999; Udo de Haes et al. 2002) or aggregated as a single score (e.g., eco-indicator).

\subsubsection{Environmental issues of wood in automotive applications}

To identify the environmental issues of wood in automotive applications, literatures dealing with bio-based and automotive product systems have been analyzed in regard to relevant environmental issues connected with specific materials as well as in regard to methodical aspects connected with either product system. Starting with LCAs of bio-based product systems, the first tangible LCAs for the forestry and wood products sector in Europe were published in in the 1990s (e.g., Frühwald and Wegener 1993 or Karjalainen and Asikainen 1996). Since then LCA has been frequently applied to assess the impacts of wood 
Fig. 3 Chosen subcategories based on UNEP/SETAC ( 2009) split in developing $(n=32)$ and developed $(n=29)$ countries (relative to total amount of the selected subcategories by the reviewed case studies)

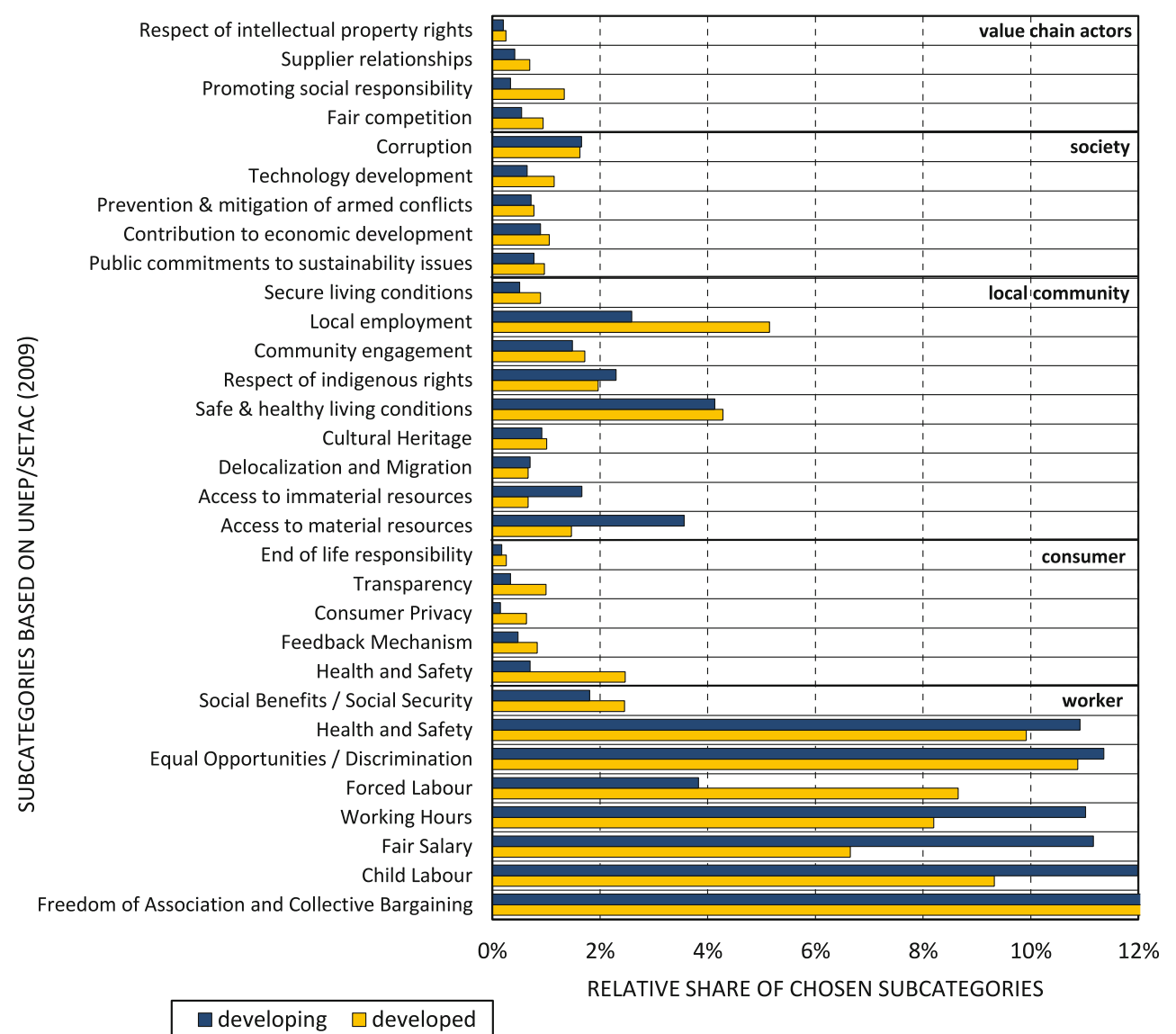

and wood-based products (see, e.g., Petersen and Solberg 2004, González-García et al. 2011b, Hesser et al. 2016 or Lettner et al. 2018). However, as, for example, stated by Klein et al. (2015), there are still no consistent and comprehensive LCA studies of wood-based production systems. Due to the multitude of

Table 4 Overview of existing LCIA methods including the respective year and geographical origin of each method (Rosenbaum et al. 2018)

\begin{tabular}{lll}
\hline LCIA methods & Year & Origin \\
\hline CML & 2001 & Netherlands \\
ReCiPe & 2009 & Netherlands \\
Eco-Indicator & 1995 & Netherlands \\
IMPACT 2002+ & 2002 & Switzerland \\
TRACI & 2003 & USA \\
EPS & 2000 & Sweden \\
EDIP & 2003 & Denmark \\
LUCAS & 2007 & Canada \\
LIME & 2003 & Japan \\
ILCD & 2012 & EU \\
EcoScarcity & 2006 & Switzerland \\
BEES & 1997 & USA \\
IMPACT World+ & 2016 & Canada, USA, Denmark, France, Switzerland \\
LC-IMPACT & 2016 & EU \\
\hline
\end{tabular}

different methods and approaches (e.g., see Hesser 2015 in terms of carbon accounting or Sutterlüty et al. 2017 in terms of water footprint), it is difficult to make a comparative statement between different studies.

When performing comparative LCAs of bio-based materials in comparison with petrochemical materials, Pawelzik et al. (2013) argue that the treatment of biogenic carbon storage is critical for quantifying the greenhouse gas emissions. However, a current shortcoming frequently discussed in the LCA community is the difficulty to fully capture the dynamic nature of carbon flows (see, e.g., Brandão et al. 2013; Lippke et al. 2011; McKechnie et al. 2011). Also, the question of whether to account for carbon storage or not is subject to ongoing debates (Levasseur et al. 2012; Pawelzik et al. 2013). The questions concerning carbon accounting are closely connected to the questions concerning land use. IPCC (2006) and EC (2010a) have published specific guidelines for calculating the carbon stock for agriculture and forestry land use. Besides following a more simplified approach, the guideline published by EC provides the possibility to calculate changes in total of carbon stocks for different soil types or land cover (Pawelzik et al. 2013).

Klein et al. (2015) reviewed LCAs in the forestry sector and found that all reviewed studies considered the global warming potential as impact category, yet, solely focusing 
on climate change as impact category may not be sufficient. In general bio-based products and an increased cultivation of biomass are connected to the risk of biodiversity loss (Koh 2007; Koh and Ghazoul 2008; Pawelzik et al. 2013). Assessing the loss of biodiversity as well as water use or soil degradation are often excluded in LCAs due to persisting methodological problems and limited data availability (dos Santos et al. 2014; Pawelzik et al. 2013). In order to overcome this limitation, the impact categories global warming, acidification, eutrophication, and ecotoxicity currently cover the main drivers of biodiversity losses (dos Santos et al. 2014; Pawelzik et al. 2013). With the impact categories fresh water aquatic ecotoxicity and terrestrial ecotoxicity, the issues of water and soil protection can be evaluated (dos Santos et al. 2014). Nevertheless, it is worth to note that methodological differences within each proxy should be considered individually. The cumulative energy demand is often used as a proxy indicator in LCA studies (Huijbregts et al. 2006).

Klein et al. (2015) focused on the methodological aspects of forest production and highlighted the large ranges of results in dependence on methodological choices, such as system boundaries and functional unit. In terms of system boundaries, most of the reviewed studies followed a cradle to gate approach. While the endpoint in the individual studies was very similar, the starting point for the assessment at the forest site varied considerably. Most of the studies actually started at the harvesting thinning/operations and thus excluded other processes such as seedling/seed production or planting (Klein et al. 2015). At the end, most of reviewed studies investigated wood for energy purposes or for pulp wood. Another aspect is the determination of the functional unit. In total Klein et al. (2015) identified 12 different functional units applied in the 24 studies. Furthermore, around $50 \%$ of the studies did not mention any characteristics of the wood or the wood-based product.

In E-LCAs focusing on automotive product systems, the potential benefits of lightweighting are often the objective of the studies since weight reduction of vehicles can lead to major environmental benefits (Hottle et al. 2017). Hottle et al. (2017) found in their review on critical factors affecting LCAs that the use phase for vehicles with combustion engines accounts for $84-88 \%$ of the life cycle emissions and energy demand, whereas the production just accounts for about 4 $7 \%$ of the energy consumption. However, the production and processing of materials can have dramatic impacts on the environment like undesirable emissions to air, water, and land or land use pattern and water use (Allwood et al. 2011).

The most commonly used material in the automotive industry is steel (Poulikidou et al. 2015), which makes up about $65-70 \%$ of the body mass (Dalmijn and de Jong 2007). Typical lightweight alternatives are high-strength steels, aluminum, magnesium, and glass or carbon fiber composites (Hottle et al. 2017; Mayyas et al. 2012b; Poulikidou et al. 2015; Raugei et al. 2015; Witik et al. 2011). All those materials are non-renewable and will eventually be exhausted up to the point where it will be too expensive to extract them; wherefore, the depletion potential and in some cases the scarcity needs to be assessed (Allwood et al. 2011; Cordella and Hidalgo 2016; Klinglmair et al. 2014).

Depending on the material to be assessed, different environmental issues are of concern, and the results vary considering different impact categories. For example, current used lightweight materials such as composites do indeed reduce weight, but the recycling is difficult, toxic, and energy intensive (Allwood et al. 2011; Diener and Tillman 2016). Consequently, using composites can lead to problems in reaching the ELV targets (European Commission 2000). Besides that, glass fibers need approximately four times more energy in the production compared to kenaf fibers (Mohanty et al. 2001) or jute fibers (Alves et al. 2010). Although natural fiber-reinforced composites may be seen as sustainable in terms of integrating renewable materials, they are not sufficiently eco-friendly because of their petroleum-based matrix (Mohanty et al. 2002).

Hottle et al. (2017) reviewed LCAs of materials for vehicle mass reduction and found that most studies assessed GHG emissions and life cycle energy use. This makes sense since those impacts are the main concern for the aluminum industry (Liu and Müller 2012) as well as for the production of magnesium (Cherubini et al. 2008). Liu and Müller (2012) mention other impact categories which should be assessed when analyzing aluminum: the toxicity of the aluminum production through emissions to air, water, and soil as well as the land use of bauxite mining and red mud generation (Liu and Müller 2012). Aluminum is ranked under the top 10 for its land use change, fresh water ecotoxicity, and final solid waste production in a top twenty priority list for the environmental profiles of materials consumed in the Netherlands (Liu and Müller 2012; van der Voet et al. 2003). van der Voet et al. (2003) published a report named "dematerialization: not just a matter of weight" where a contribution of materials to 13 environmental impact categories consumed in the Netherlands is provided. They screened and summarized for each impact category the top 20 contributions of materials to environmental problems. Their results show that steel and iron contribute to depletion of abiotic resources, land use competition, as well as fresh water ecotoxicity (van der Voet et al. 2003). The materials such as high-alloyed steel, aluminum, and plastics contribute at least to ten out of 13 impact categories (Table 5).

\subsubsection{Factors influencing methodical choices in E-LCA}

In total 33 E-LCA case studies of wood-based products and 32 E-LCA case studies of automotive components were identified. An overview of the identified E-LCA case studies is provided in Table 6, where the 65 case studies are categorized according to the focus of the study (E-LCA of wood or automotive 
Table 5 Environmental problems of selected materials (van der Voet et al. 2003)

\begin{tabular}{|c|c|c|c|c|}
\hline & Steel and iron & Steel-high alloyed & Aluminum & Plastics \\
\hline Depletion of abiotic resources & $\mathrm{x}$ & $\mathrm{x}$ & $\mathrm{x}$ & $\mathrm{x}$ \\
\hline Land use competition & $\mathrm{x}$ & $\mathrm{x}$ & $\mathrm{x}$ & $\mathrm{x}$ \\
\hline Climate change & & & $\mathrm{x}$ & $\mathrm{x}$ \\
\hline Stratospheric ozone depletion & & & $\mathrm{x}$ & $\mathrm{x}$ \\
\hline Human toxicity & & $\mathrm{x}$ & $\mathrm{x}$ & $\mathrm{x}$ \\
\hline Fresh water ecotoxicity & $\mathrm{x}$ & $\mathrm{x}$ & $\mathrm{x}$ & $\mathrm{x}$ \\
\hline Marine ecotoxicity & & $\mathrm{x}$ & $\mathrm{x}$ & $\mathrm{x}$ \\
\hline Terrestrial ecotoxicity & & $\mathrm{x}$ & $\mathrm{x}$ & $\mathrm{x}$ \\
\hline Photochemical oxidant formation & & $\mathrm{x}$ & $\mathrm{x}$ & $\mathrm{x}$ \\
\hline Acidification & & $\mathrm{x}$ & $\mathrm{x}$ & $\mathrm{x}$ \\
\hline \multicolumn{5}{|l|}{ Eutrophication } \\
\hline Radiation & & $\mathrm{x}$ & $\mathrm{x}$ & $\mathrm{x}$ \\
\hline Final solid waste & & $\mathrm{x}$ & $\mathrm{x}$ & \\
\hline
\end{tabular}

components) and the objective of the reviewed studies. The objectives of E-LCA literature were grouped into six categories: method development, impacts of lightweighting, material substitution, re-/eco-design, material development, and life cycle inventory. A description of each category is provided in Table 7 .

Besides studying the E-LCA literature for the objective, it was further analyzed for the chosen impact categories (Table 8) and LCIA methods (Table 4). For further analysis, the LCIA methods rarely used in the studies (EPS, EDIP, ILCD, BEES) as well as the characterization model USEtox are grouped into "Others." Another possibility to do the LCIA is by calculating the cumulative energy demand (CED) (Huijbregts et al. 2006; Huijbregts et al. 2010). Several studies calculated the global warming potential (GWP) by referring to the latest IPCC characterization factors (IPCC 2013) which is also included in several LCIA methods like in CML. Some studies did not mention a particular LCIA approach but performed own calculation with, e.g., energy-related indicators - those studies were categorized into the LCIA group own calculations.

A common practice is to explain the choice of certain impact categories and indicators by referring to previous studies with a similar research focus, which is also suggested by Höglmeier et al. (2016). However, the use of categories that have been selected in comparable studies does not mean that all relevant aspects are automatically taken into account. Therefore, the literature sample was screened to identify the impact categories chosen to assess wood as well as automotive product systems. In total over 50 differently named impact categories were identified in the E-LCA sample. An overview of all identified impact categories is provided in the appendix. In order to identify potential tendencies between impact category choice and, e.g., the analyzed material as well as to reduce the complexity of the identified impact categories, those over 50 identified impact categories were grouped into 14 impact category groups (Table 8 ) according to the overview provided by Rosenbaum (2018). The grouping was done (a) on the basis of the unit used to express an impact category, (b) based on the theme addressed, e.g., the CA group contains carcinogenic and non-carcinogenic impact categories (c) if similar environmental issues were addressed as in the groups BD and RRU, and (d) when the impact category was used just once or twice they were included into a group others. A more detailed overview of the grouping including the units and their respective LCIA methods is provided in the appendix.

The results of the content analysis show that more than half of the studies used software support to perform the E-LCA. Most of them used SimaPro followed by GaBi, Umberto, OpenLCA, or ATHENA. Using software support can influence the choice of an LCIA method since those software solutions have various LCIA methods implemented (Rosenbaum et al. 2018; SimaPro 2019). Incidentally, 78\% of the studies which performed own calculation had no LCA software support. The availability of the characterization sheet of an LCIA method could be another argument for choosing one LCIA method over the other. The results of the present study show that $56 \%$ of the studies where TRACI was chosen for LCIA used no software support. The environmental impact assessment tool TRACI includes characterization factors for the LCIA and is available for free at the EPA homepage (EPA 2016). The same is possible with CML-IA, where the characterization factors can be downloaded at the homepage of Leiden University. ${ }^{2}$

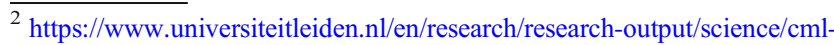
ia-characterisation-factors
} 
Table 7 E-LCA literature sample $(n=65)$ categorized by focus and aim of the study

\begin{tabular}{|c|c|c|}
\hline Aim & Focus & Author(s) (year of publication) \\
\hline \multirow{2}{*}{$\begin{array}{l}\text { Method } \\
\text { development }\end{array}$} & Wood & Höglmeier et al. (2014) \\
\hline & Automotive & Poulikidou et al. (2015), Mayyas et al. (2012b), Ribeiro et al. (2007), Geyer (2008), Fitch and Cooper (2003) \\
\hline $\begin{array}{l}\text { Impacts of } \\
\text { lightweighting }\end{array}$ & Automotive & $\begin{array}{l}\text { Das (2000), Das (2014), Duflou et al. (2009), van Acker et al. (2009), Kim et al. (2010), Geyer (2008), } \\
\text { Raugei et al. (2015), Ding et al. (2016), Delogu et al. (2017), Koffler (2014) }\end{array}$ \\
\hline \multirow{2}{*}{$\begin{array}{l}\text { Material } \\
\text { substitution }\end{array}$} & Wood & Petersen and Solberg (2004) \\
\hline & Automotive & $\begin{array}{l}\text { Akhshik et al. (2017), Alves et al. (2010), dos Santos et al. (2014b), Das (2011), Dubreuil et al. (2012), Hardwick } \\
\text { and Outteridge (2016), Puri et al. (2009), Sun et al. (2017), Song et al. (2009), Tharumarajah and Koltun (2007), } \\
\text { Witik et al. (2011), Wötzel et al. (1999), Zah et al. (2007) }\end{array}$ \\
\hline \multirow[t]{2}{*}{$\begin{array}{l}\text { Re-design/ } \\
\text { Eco-design }\end{array}$} & Wood & $\begin{array}{l}\text { Bolin and Smith (2011a, 2011b, 2011c), Cobut et al. (2015), dos Santos et al. (2014), Frenette et al. (2010), } \\
\text { González-García et al. (2011a), González-García et al. (2011b), González-García et al. (2012), Hesser et al. } \\
\text { (2016), Lee and Xu (2004), Lu and El Hanandeh (2016), Noda et al. (2016), Petersen and Solberg (2002) }\end{array}$ \\
\hline & Automotive & Boland et al. (2016), Ermolaeva et al. (2004), Ribeiro et al. (2007) \\
\hline \multirow{2}{*}{$\begin{array}{l}\text { Material } \\
\text { development }\end{array}$} & Wood & Hesser (2015), La Rosa et al. (2014), Mahalle et al. (2014), Sommerhuber et al. (2017), Xu et al. (2008) \\
\hline & Automotive & Luz et al. (2010) \\
\hline \multirow[t]{2}{*}{$\begin{array}{l}\text { Life cycle } \\
\text { inventory }\end{array}$} & Wood & $\begin{array}{l}\text { Cambria and Pierangeli (2012), García-Durañona et al. (2016), Gasol et al. (2008), González-García et al. (2009), } \\
\text { Hu et al. (2018), Laurent et al. (2013), Nakano et al. (2018), Park et al. (2018), Petersen and Solberg (2004), } \\
\text { Phungrassami and Usubharatana (2015), Rivela et al. (2007; 2006), Wenker et al. (2016) }\end{array}$ \\
\hline & Automotive & Hakamada et al. (2007) \\
\hline
\end{tabular}

Studies mentioned more than once means that multiple objectives were formulated

Other influencing factors for the choice of an LCIA approach might be the availability and up-to-dateness of a method as well as the geographical scope of the study. In the reviewed E-LCA literature CML was used only after the year 2006, ReCiPe after 2013, TRACI and IMPACT2002+ only after 2009, and Ecoindicator95/99 only before 2010. Looking at the year when a certain LCIA method was first introduced (Table 4) plus a few years until a study first uses a new method, the results are not surprising. The geographical focus of a study can also influence the choice of an LCIA method, e.g., all studies which defined the geographical scope to be North America used TRACI as LCIA method.

From the 65 studies, 95\% considered climate change (CC) impact categories. Over 60\% assessed acidification and eutrophication whereas ozone depletion, abiotic resource use, respiratory effects, or impacts measured by energy demand have been analyzed by over $50 \%$. Just little difference could be found between impact category choice and focus of the study, but, e.g., bio-based materials were more often analyzed with impact categories like acidification, abiotic resource use, eutrophication, or ecotoxicity (Fig. 5). The latter can at least be partly

Table 6 Objectives of the reviewed E-LCA studies

\begin{tabular}{|c|c|}
\hline Aim & Description \\
\hline Method development & $\begin{array}{l}\text { The study focused on (further) developing a method, framework, or model for sustainable material selection, assessing light- } \\
\text { weight strategies, for life cycle engineering or for assessing cascading systems }\end{array}$ \\
\hline $\begin{array}{l}\text { Impacts of } \\
\text { lightweighting }\end{array}$ & $\begin{array}{l}\text { Several studies analyzed the potential benefits of a weight reduction by calculating the emission saving potentials of using lighter } \\
\text { materials for the vehicle }\end{array}$ \\
\hline Material substitution & $\begin{array}{l}\text { The focus was on assessing the environmental impacts of constructing a component or product with a different material. } \\
\text { The focus of the study was on the material of a certain component }\end{array}$ \\
\hline $\begin{array}{l}\text { Re-design / } \\
\text { Eco-design }\end{array}$ & $\begin{array}{l}\text { The studies focused on environmental conscious product development and therefore on assessing the environmental impacts of } \\
\text { redesigned or eco-designed components or products and often involved more components and materials }\end{array}$ \\
\hline Material development & The studies assessed the environmental impacts of newly developed materials and compared them with conventional materials \\
\hline Life cycle inventory & $\begin{array}{l}\text { The objective of the study was on producing generic LCI data for a region, life cycle stage, material, product, or certain practices } \\
\text { as well as in some cases to identify hotspots in the product system }\end{array}$ \\
\hline
\end{tabular}


Table 8 Overview of the identified impact categories in the reviewed literature grouped into 14 category groups for further analysis. A more detailed overview is available in the appendix

\begin{tabular}{lll}
\hline Acronym & Category & Impact categories \\
\hline AC & Acidification & Terrestrial or aquatic acidification \\
ARU & Abiotic resource use & Abiotic depletion potential, fossil fuel depletion, mineral extraction \\
BD & Biodiversity and land use & Land occupation, biodiversity, biotic production potential \\
CA & Carcinogenic effects & Carcinogenics and non-carcinogenics \\
CC & Climate change & Global warming potential, GHG emissions \\
ED & Energy demand & Cumulative energy demand, cumulative non-renewable energy use \\
ET & Eutrophication & Marine or terrestrial eutrophication \\
Etox & Ecotoxicity & Aquatic ecotoxicity, terrestrial ecotoxicity \\
HT & Human toxicity & Human toxicity potential \\
IR & Ionizing radiation & Ionizing radiation \\
OD & Ozone depletion & Ozone layer depletion \\
Others & - & Solid waste, heavy metals, pesticides \\
RE & Respiratory effects & Respiratory effects organics and inorganics, smog potential, photo-oxidants creation potential \\
RRU & Renewable resource and water use & Consumption of renewable resources, water intake, water depletion \\
\hline
\end{tabular}

explained by the fact that E-LCAs of wood products chose more often CML as an LCIA method which already includes several different impact categories (Fig. 4).

Numerous different materials were analyzed in the E-LCA literature. In order to analyze relations between a material and the LCIA method or impact category for bio-based materials in the automotive industry, the materials were categorized into eight material groups (glass or carbon fiber composites (G/CFRC); steel (including boron, stainless, or high strength steel); aluminum, wood and engineered wood products (e.g., wood, glulam, MDF, OSB, or particleboards); plastics (e.g., polypropylene); natural fiber reinforced composites (NFRC,

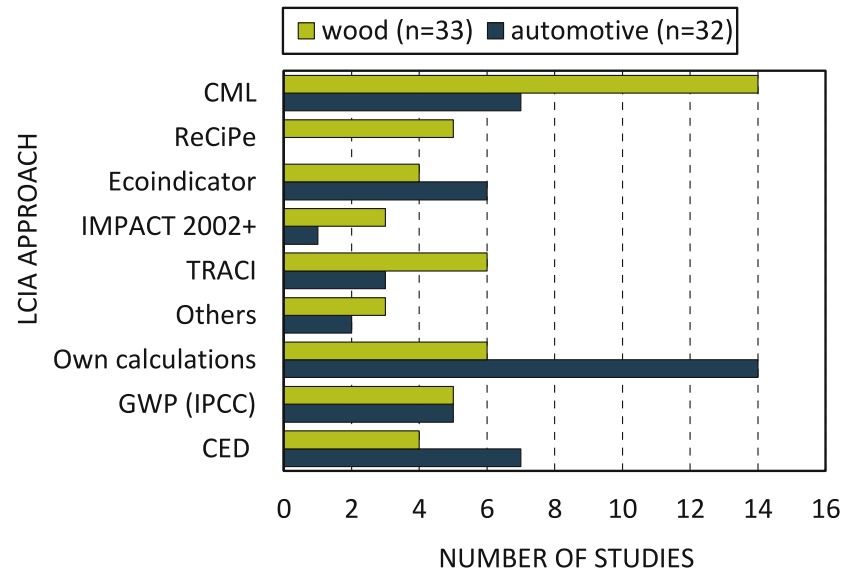

Fig. 4 LCIA approaches chosen by the reviewed E-LCA studies either focusing on wood or on automotive (absolute numbers). Some case studies chose more than one LCIA approach e.g., with kenaf, jute or wood); magnesium; and other materials (e.g., mineral reinforced composites or concrete)). The latter two were not considered for further analysis.

The impact category choice per material analyzed is illustrated in Fig. 5. Figure 6 illustrates the LCIA method chosen for assessing different materials. When just comparing the choice of impact categories between two materials, especially when comparing bio-based (natural fiber reinforced composites and engineered wood products) versus steel, aluminum, and composites, the results show that the latter materials were more often analyzed with energy-related impact categories. The studies analyzing bio-based materials more often chose various impact categories. However, this can also be explained by the fact that studies focusing on wood more often used CML for LCIA (see Fig. 4) which already includes different impact categories, whereof automotive studies more often did the LCIA with own calculations. Most studies, which did not mention any LCIA approach, performed their own calculations or added impact categories not covered in their chosen LCIA method (mostly climate change and/or energy demand impacts). The materials assessed in the "own calculation" studies are steel (48\%) and aluminum (58\%) (Fig. 6).

Analyzing the LCIA approach chosen per objective of a study, the results show that studies focusing on material development and life cycle inventory more often chose CML, whereas studies focusing on impacts of lightweighting and method development more often performed own calculations. The latter might be explained by the fact that automotive studies mostly aimed at 


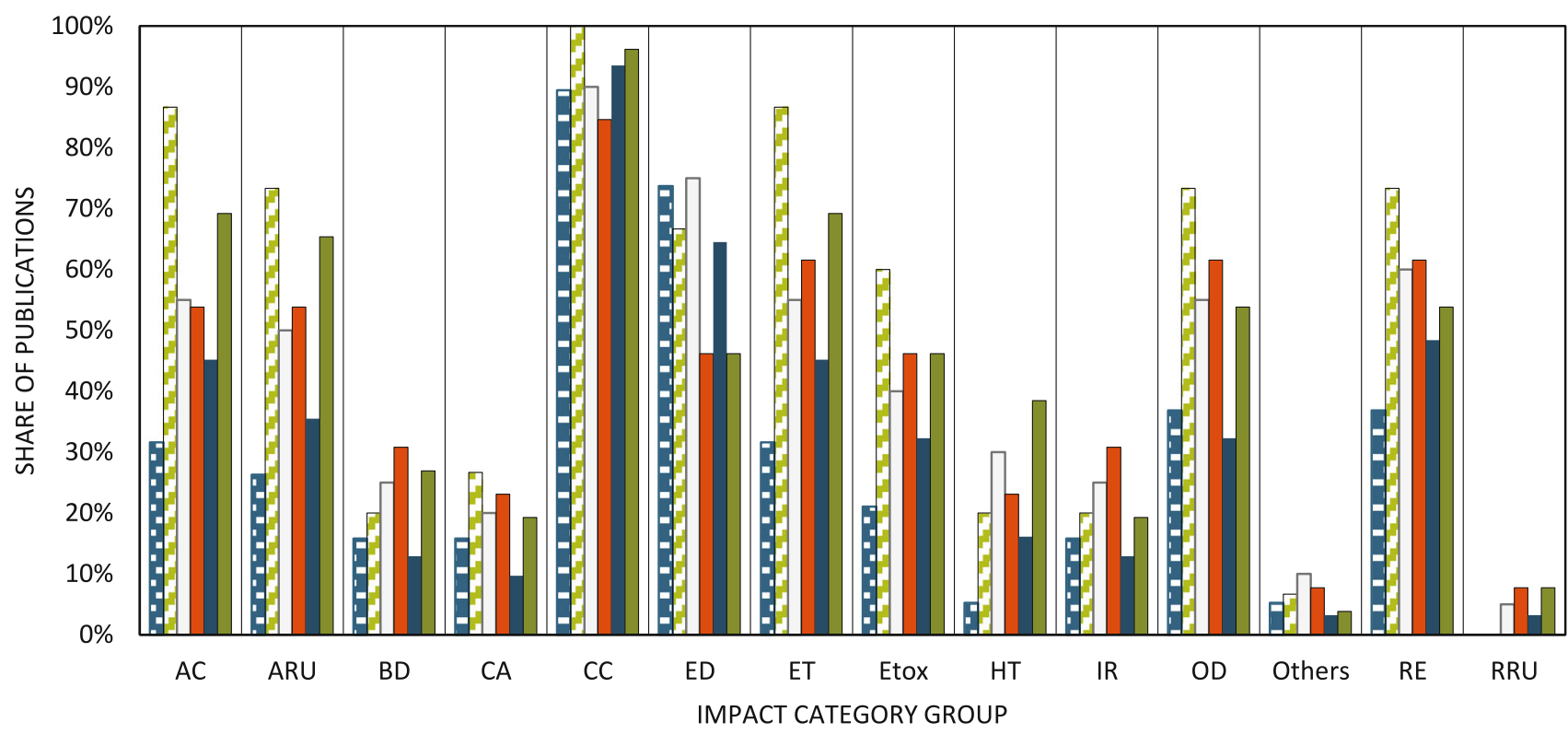

- Aluminium $(n=19)$

$\square \operatorname{NFRC}(n=15)$

$\square \mathrm{G} / \mathrm{CFRC}(\mathrm{n}=20)$

$\square$ Plastics $(n=13)$

- Steel $(\mathrm{n}=31)$

$\square$ EWPs $(n=26)$

Fig. 5 Impact categories chosen for assessing different materials relative to the total number of studies that examined this material (NFRC - natural fiber-reinforced composites; G/CFRC - glass or carbon fiber-reinforced composites; EWPs - engineered wood products). The description of impact category groups including their abbreviations is provided in Table 8 assessing material substitution effects, identifying potential benefits of lightweighting, or developing a method for sustainable material selection (Fig. 7). On the contrary, E-LCAs of wood products focused more often on life cycle inventories, material development, or re-/ eco-design. The results of Fig. 7 are in line with the results presented in Fig. 4: here E-LCAs of wood products more often chose CML whereas automotive
E-LCAs more often performed own calculations. All of the automotive studies analyzed the whole life cycle of the product under study. On the contrary, only $45 \%$ of the wood E-LCAs considered the whole life cycle in their analysis whereof the other $55 \%$ consider just parts of the life cycle, mostly from cradle to grave of which $70 \%$ aimed at analyzing the life cycle inventory of several processes.
Fig. 6 LCIA methods chosen for assessing different materials relative to the total number of studies that examined this material (NFRC - natural fiberreinforced composites; G/CFRC glass or carbon fiber-reinforced composites; EWPs - engineered wood products)

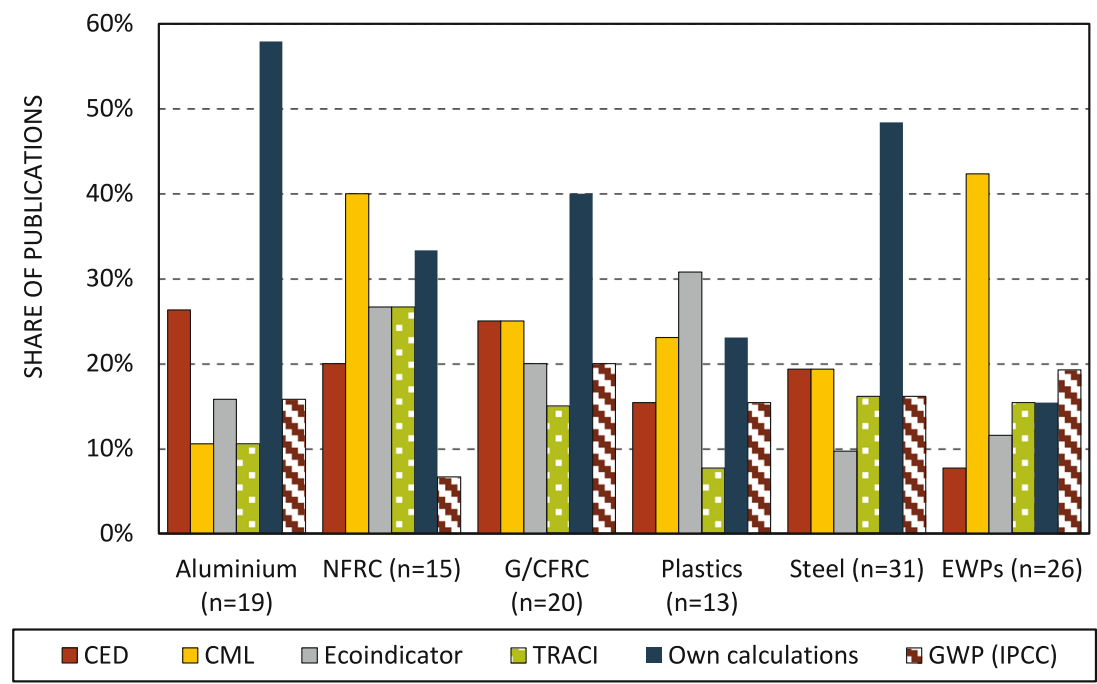




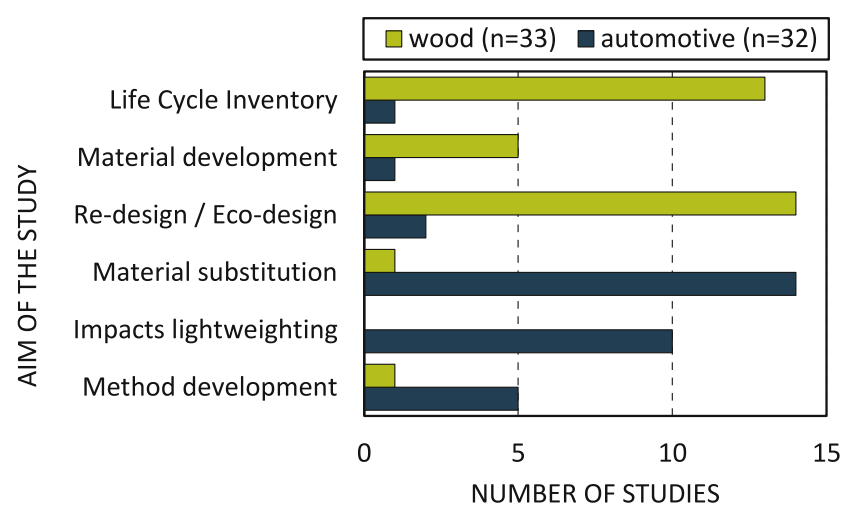

Fig. 7 Aim of the reviewed E-LCA studies either focusing on wood or automotive (absolute numbers)

\section{Discussion and conclusion}

The aim of the conducted literature review was to identify the relevant social topics and environmental issues when assessing wood in automotive applications as well as to shed light on the factors influencing the choice of the respective methods, impact categories, and indicators. The first step was to gain knowledge about (RQ1) which environmental and social impact categories or subcategories are considered in the literature and secondly to systematically analyze the factors shaping the choice of methods, impact categories, and indicators in environmental and social LCA (RQ2).

\subsection{Relevant social and environmental issues}

In order to identify relevant social and environmental issues, literature dealing with these topics was reviewed. The results of this review show that most of the S-LCA case studies performed so far, referred to the subcategories proposed by the UNEP/ SETAC (2009) guidelines. Additional relevant social topics for bio-based product systems could be identified (see Table 1), such as food security or land- and worker-related concerns. Although the identified social impacts listed in Table 1 can be a good starting point to decide for impact categories and indicators for bio-based product systems, it might not be complete yet. S-LCAs specific for bio-based product systems are still very limited in order to analyze and compare the different methodologies and indicators chosen in the case studies. Furthermore, there is a risk that potentially relevant indicators will be neglected, if only the indicators of the UNEP/SETAC (2009) guideline are taken into account. Nevertheless, the literature suggests that the geographical and sectorial context determine methodical choices in the case of S-LCA (see in Benoit et al. 2010; Dreyer et al. 2010a; Garrido et al. 2018; Hunkeler 2006; Sanchez Ramirez et al. 2014; Siebert et al. 2018a; Siebert et al. 2018b).

Regarding E-LCA the literature suggests that the objective and material type determine calculation approaches and impact category choices (EC 2010c; ISO 2006a; Rosenbaum et al. 2018); for instance, GWP is described as a major concern in the automotive industry as well as in the production of certain materials like aluminum or magnesium (Cherubini et al. 2008; Hottle et al. 2017; Liu and Müller 2012). However, some authors recommend to consider additional impact categories, e.g., biodiversity for bio-based systems, where the main drivers of biodiversity loss can be covered with the impact categories global warming potential, acidification, eutrophication, and ecotoxicity (dos Santos et al. 2014; Klein et al. 2015; Pawelzik et al. 2013); the depletion potential or scarcity indicators for non-renewable materials (Allwood et al. 2011; Cordella and Hidalgo 2016; Klinglmair et al. 2014); or ecotoxicity for steel and toxicity in the case of aluminum (see Table 5) (Liu and Müller 2012; van der Voet et al. 2003).

\subsection{Factors influencing methodical choices}

To gain insights on the factors that shape the choice of methods and indicators in environmental and social LCA, a content analysis approach of three literature samples (all published S-LCA case studies; E-LCA case studies focusing on wood products or on components in automotive applications) was performed. The sample was analyzed covering the following criteria: considered stakeholder groups and chosen subcategories (S-LCA), sector or product system (S-LCA), year of publication and geographical scope (S-LCA and E-LCA), chosen LCIA method(s) and impact categories, objective(s) of the studies, analyzed materials and used software support (E-LCA).

In S-LCAs the identification of relevant countries and sectors as well as the targeted stakeholder groups is central in order to identify relevant social aspects (subcategories, indicators) (Dreyer et al. 2010a; Jørgensen 2013; UNEP/SETAC 2009). The results of the present study show that the stakeholder groups value chain actors, society, local community, and worker who were chosen slightly more often when S-LCAs were conducted focusing on developing countries. Hereby, the biggest differences can be observed for the stakeholder group worker (see Fig. 3). Only the stakeholder group consumer has been chosen more often for developed countries. In globalized value chains, the steps in the production phase, such as resource extraction, are often located in developing countries; hence, the focus on the stakeholder group workers can be explained. Following, the consumers as stakeholder groups affected during the use-phase are considered in studies conducted in developed countries. This is also reflected in the choice of indicators. The indicators child labor, fair salary, working hours, and access to material resources have been slightly more often chosen in developing countries, and two indicators have been slightly more often chosen in developed countries (forced labor and local employment). For example, in the case of child labor, studies showed that poverty drives this social issue in developing countries because the income of child labor is highly needed (Arvidsson et al. 2015). Following it can be assumed that the socio-political context is reflected in the selection of 
indicators. However, within the 50 case studies under investigation, the results showed not as many differences as might be expected. It has to be noted that this study included only a small sample, yet it included all available case studies at the date of analysis. No clear connection between the geographical area and the choice of subcategories/indicators could be found within the present study. Petti et al. (2018) did a review on S-LCA and came to a similar conclusion that the geographical area has just a minor influence on the choice of social indicators. They also found that over $40 \%$ of the S-LCAs conducted have been performed in European countries where the highest concentration of researchers can be observed (Mattioda et al. 2015; Petti et al. 2018). A general problem in S-LCAs focusing on developing countries might be data availability (Petti et al. 2018). The difficulty in finding data (e.g., socially sensitive ones) could be one reason why fewer studies than expected were conducted in developing countries (Petti et al. 2018). Especially in developing countries, it could be important to implement S-LCAs in order to identify the hotspots to improve the social conditions on site (Petti et al. 2018).

The environmental issues related to the production of materials are diverse, yet most studies focus on assessing the impacts on climate change (95\%). Similar results are shown by Hottle et al. (2017) in context of automotive LCAs, which is probably connected to the emission performance standards of the European Commission (2014). The results of the present study show that climate change is also the most chosen indicator in LCAs of wood-based products and Klein et al. (2015) found the same result on LCAs of forest productions. In the analyzed case studies, over $60 \%$ assessed acidification and eutrophication, whereas ozone depletion, abiotic resource use, respiratory effects, or impacts measured by energy demand have been analyzed by over $50 \%$. Over $30 \%$ of the analyzed case studies focused just on one or two indicators, which is relatively modest considering the environmental issues connected with materials. However, just because a category is chosen by a lot of different studies, it does not imply that this is an environmental issue to be included as recommended by EC (2010b) and ISO (2006a). One way to identify relevant impact categories for a specific product system is to screen results of different impact categories after an LCA study has been performed. Using software support facilitates this since various LCIA approaches covering various impact categories are partly already implemented in LCA software (Rosenbaum et al. 2018; SimaPro 2019). This means the environmental issues connected with a system can at least be identified after the LCA has been performed by analyzing the results of the LCA. If no software support is available, the identification of the relevant environmental issues is more complex and time-consuming than with software support. For that the characterization tables of CML or TRACI can be used, although here data must be available and in the case of ex-ante assessment data availability is an issue. If no resources for software support or generic databases such as
Ecoinvent are available, researchers and practitioners have to rely on preliminary studies with a similar research focus. In that way, insights into the relevant environmental issues for specific product systems are gathered, which might help in the selection of impact categories. Another possibility on how to deal with the issue of no software support or no generic database available is to use CED as a proxy for the environmental burden of impacts, as recommended by Huijbregts et al. (2006). However, CED looks only into the primary energy demand, and other environmental impacts are not covered.

In the present study it could be shown that the identification of relevant environmental issues of wood in automotive applications is difficult, also when referring to previous studies with similar research focus. In the studies analyzed, the choice for a certain impact category or LCIA approach was often not argued or was influenced by more than just the environmental issues connected with the system under study. In the conducted literature review influencing factors such as the objective of the study, the up-to-dateness of the LCIA approach, the geographical scope of the study, the materials analyzed, and the software support have been identified by reviewing and analyzing relevant literature. The two investigated samples on E-LCA of wood products and of automotive components had quite different objectives (Fig. 7), which might be one explanation for the different choice of LCIA approaches (Fig. 4). Other influencing factors for methodical choices might be data availability or the usage of software support. The former was rarely mentioned within the studies analyzed. The latter is not always available, e.g., due to limited budgets or tradition (e.g., Excel as the usual tool). The results show that $40 \%$ did not mention any software support, of which the majority (80\%) did not mention the LCIA approach or calculated the LCIA on their own. However, analyzing the potential environmental impact with a whole set of impact categories is easier when using software support. Other influencing factors might be the up-to-dateness of the LCIA approach or the geographical scope of the study. In case of the geographical scope of the study, it could be shown that it can influence the choice for an LCIA approach, e.g., all studies which defined the geographical scope to be North America used TRACI as LCIA method. Regarding the influence of the material analyzed on the choice of impact category, it was found that studies which analyzed product systems involving wood products or natural fiber composites more often chose impact categories such as acidification, eutrophication, abiotic resource use, or ozone depletion (see Fig. 5). However, this might be connected to the fact that LCAs of wood products more often performed the LCIA with CML (Fig. 4) and therefore with various impact categories.

\subsection{Limitations and outlook}

The aim of this study was to shed some light on the choice of impact categories and LCIA approach for E-LCA and 
subcategories and indicators for S-LCA when assessing the environmental and social performance of wood-based components in automotive applications. The applied methods, literature review, and content analysis are subject to some typical limitations, i.e., selection of literature and criteria for coding might be biased by the researcher conducting the study, the aspects discussed depend on other authors work in this field, setting the boundaries according to the research question for the literature search as well as discriminating between relevant and irrelevant literature (e.g., Engert et al. 2016).

Some relevant environmental and social impact categories as well as influencing factors in methodical choices could be identified from existing literature. However, a clear picture on these issues could not be drawn, e.g., concrete recommendations on material-related environmental issues or geographical-related social topics could not be found when reviewing the literature focusing on automotive or wood-based product systems. Expanding the literature sample to include LCAs of other product systems most likely enables to generate additional knowledge on relevant social and environmental issues for specific product systems.

Identifying the relevant impact categories before conducting a study is a general problem (not just for assessing wood in vehicles), and the literature review carried out shows that this problem can be confirmed for the specific case of wood in automotive applications. The results of the present study are based on a small sample, namely, E-LCAs of wood-based or automotive product systems and S-LCA case studies. Further research might analyze if LCAs of other product systems face similar challenges in identifying the relevant environmental and social issues as well as in selecting the appropriate impact categories and assessment methods for the system under study.

Further knowledge on methodical choices might be gained by social science research on, e.g., the motivation of researchers to choose a certain LCIA approach or impact category in E-LCA or subcategory and indicator in S-LCA. This may provide an understanding of what information and guidance researchers and practitioners may consider regarding methodological decisions for specific product systems. A starting point for providing guidance on the identification of environmental and social issues for specific product systems could be based on environmental issues connected with materials or geographical-related social topics. Furthermore, there is currently neither a full E-LCA nor an S-LCA case study of wood-based products for automotive applications available. Such a study would be needed to address the differences in assessing bio-based and non-bio-based products and in particular the extent to which those products are comparable in terms of the different environmental issues that should be considered for each system.

\section{Appendix}

Table 9 Categorization of identified impact categories based on Rosenbaum (2018), Jolliet et al. (2003) and Lippiat (2007)

\begin{tabular}{|c|c|c|c|c|}
\hline Acronym & Category & Impact category & Unit & LCIA method \\
\hline \multirow[t]{2}{*}{$\mathrm{CC}$} & \multirow[t]{2}{*}{ Climate change } & global warming potential & $\mathrm{kg} \mathrm{CO} 2$ eq & $\begin{array}{l}\text { IMPACT2002+ | EI99 | TRACI | CML | EDIP | } \\
\text { ReCiPe | ILCD | IMPACTworld+ | BEES }\end{array}$ \\
\hline & & greenhouse effect & GWP kg & EI95 \\
\hline \multirow[t]{4}{*}{ ED } & \multirow[t]{4}{*}{ Energy demand } & cumulative energy demand & MJ & CED | ILCD \\
\hline & & $\begin{array}{l}\text { primary energy } \\
\text { consumption }\end{array}$ & MJ & TRACI \\
\hline & & $\begin{array}{l}\text { Cumulative non-renewable } \\
\text { energy use }\end{array}$ & MJ & \\
\hline & & non-renewable energy & MJ primary & IMPACT2002+ | EI99 \\
\hline \multirow[t]{5}{*}{ ARU } & \multirow[t]{5}{*}{$\begin{array}{l}\text { Abiotic resource } \\
\text { use }\end{array}$} & $\begin{array}{l}\text { abiotic depletion fossil and } \\
\text { non-fossil resources }\end{array}$ & MMBTU & \\
\hline & & $\begin{array}{l}\text { abiotic depletion potential } \\
\text { (non-renewable } \\
\text { resources) }\end{array}$ & $\begin{array}{l}\text { ADP } \mid \text { person reserve } \mid \text { marginal } \\
\text { increase of extraction costs } \mid \mathrm{kg} \\
\text { Sb-eq. }\end{array}$ & CML-IA | EDIP | ReCiPe | ILCD \\
\hline & & resource intensity & $\mathrm{kg}$ & ILCD \\
\hline & & $\begin{array}{l}\text { fossil fuels depletion / fossil } \\
\text { use }\end{array}$ & MJ deprived & EI99 | TRACI | IMPACTworld+ | BEES 2.0 \\
\hline & & $\begin{array}{l}\text { Mineral, Metal extraction / } \\
\text { depletion }\end{array}$ & MJ surplus $\mid \mathrm{kg}$ eq. Of iron in ore & $\begin{array}{l}\text { IMPACT2002+ | EI99 | IMPACTworld+ } \\
\text { |ReCiPe }\end{array}$ \\
\hline \multirow[t]{5}{*}{ RRU } & \multirow{5}{*}{$\begin{array}{l}\text { Renewable } \\
\text { resource and } \\
\text { water use }\end{array}$} & water intake & liters & BEES 2.0 \\
\hline & & water deprivation & $\mathrm{m} 3$ world eq. & ILCD | IMPACTworld+ \\
\hline & & consumptive water use & & EI99 \\
\hline & & water depletion & & EI99 | ReCiPe \\
\hline & & wood consumption & t softwood standing trees & \\
\hline
\end{tabular}


Table 9 (continued)

\begin{tabular}{|c|c|c|c|c|}
\hline Acronym & Category & Impact category & Unit & LCIA method \\
\hline & & $\begin{array}{l}\text { consumption of renewable } \\
\text { resources }\end{array}$ & & \\
\hline \multirow[t]{4}{*}{$\mathrm{AC}$} & \multirow[t]{4}{*}{ Acidification } & winter smog & & EI95 \\
\hline & & acidification & $\mathrm{H}+$ eq. & EI99 | BEES 2.0 \\
\hline & & terrestrial acidification & $\begin{array}{l}\text { kg SO2 eq } \mid \mathrm{H}+\text { eq. }|\mathrm{BS}[\mathrm{m} 2 * \mathrm{y}]| \mathrm{mol} \\
\mathrm{H} \text { eq. }\end{array}$ & $\begin{array}{l}\text { IMPACT2002+ | CML-IA | TRACI | EDIP | } \\
\text { ReCiPe | ILCD | IMPACTworld+ }\end{array}$ \\
\hline & & aquatic acidification & $\mathrm{kg} \mathrm{SO} 2 \mathrm{eq}$ & IMPACT2002+ | IMPACTworld+ \\
\hline OD & Ozone depletion & ozone layer depletion & kg CFC-11 eq & $\begin{array}{l}\text { IMPACT2002+ | EI99 | TRACI | CML | EDIP | } \\
\text { ReCiPe | ILCD | IMPACTworld+ | BEES }\end{array}$ \\
\hline \multirow[t]{4}{*}{ ET } & \multirow[t]{4}{*}{ Eutrophication } & marine eutrophication & $\operatorname{kg~N} \mid \operatorname{vkgN~N-lim}$ & ReCiPe | ILCD | IMPACTworld \\
\hline & & eutrophication & $\mathrm{N}$ eq & EI99 |BEES 2.0 \\
\hline & & terrestrial eutrophication & $\mathrm{PO}^{3-}{ }_{4}$ eq $|\mathrm{m} 2| \mathrm{mol} \mathrm{N}$ eq. & CML-IA | IMPACT2002+ | EDIP | ILCD \\
\hline & & freshwater eutrophication & $\begin{array}{l}\mathrm{PO}^{3-}{ }_{4} \text { eq. } \mid \text { kg PO4 P-lim | NO3eq. | kg } \\
\quad \mathrm{N} \mid \mathrm{kg} \mathrm{P}\end{array}$ & $\begin{array}{l}\text { IMPACT2002+ | CML-IA | TRACI | EDIP | } \\
\text { ReCiPe | ILCD | IMPACTworld+ }\end{array}$ \\
\hline \multirow[t]{8}{*}{ Etox } & \multirow[t]{8}{*}{ Ecotoxicity } & ecotoxicity & CTUe $\mid 2,4-D$ eq & EI99 | BEES \\
\hline & & aquatic ecotoxicity & kg TEG water & IMPACT2002+ \\
\hline & & $\begin{array}{l}\text { freshwater aquatic } \\
\text { ecotoxicity }\end{array}$ & 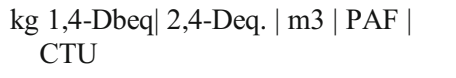 & $\begin{array}{l}\text { CML | TRACI } \mid \text { EDIP } \mid \text { ReCiPe } \mid \text { ILCD } \mid \\
\text { IMPACTworld+ }\end{array}$ \\
\hline & & marine aquatic ecotoxicity & kg 1,4-Dbeq & CML | ReCiPe \\
\hline & & terrestrial ecotoxicity & kg 1,4-Dbeq | kg TEG soil | m3 & CML | IMPACT2002+ | EDIP | ReCiPe \\
\hline & & marine sediment & kg 1,4-Dbeq & CML \\
\hline & & freshwater sediment & kg 1,4-Dbeq & CML \\
\hline & & water pollution & $\mathrm{kg}$ & \\
\hline \multirow[t]{7}{*}{$\mathrm{RE}$} & \multirow[t]{7}{*}{$\begin{array}{l}\text { Respiratory } \\
\text { effects }\end{array}$} & respiratory effects organics & $\begin{array}{l}\mathrm{kg} \mathrm{C} 2 \mathrm{H} 4 \mathrm{eq}|\mathrm{nmVOCeq}| \\
\text { person*ppm*h }\end{array}$ & $\begin{array}{l}\text { IMPACT2002+ | EI99 | EDIP | ReCiPe } \mid \\
\text { IMPACTworld+ }\end{array}$ \\
\hline & & $\begin{array}{l}\text { respiratory effects } \\
\text { inorganics }\end{array}$ & PM2.5 eq | PM10 eq. & $\begin{array}{l}\text { TRACI | IMPACT2002+ | EI99 | ILCD | } \\
\text { IMPACTworld+ }\end{array}$ \\
\hline & & particulate matter formation & PM10eq. & ReCiPe \\
\hline & & $\begin{array}{l}\text { photo-oxidants creation } \\
\text { potential }\end{array}$ & C2H4 eq. | ethylene eq. & CML | IMPACT 2002+ \\
\hline & & summer smog & POCP kg & EI95 \\
\hline & & nitrogen oxides & Nox eq. & TRACI \\
\hline & & smog potential & $\mathrm{O} 3$ eq. $\mid \mathrm{NOx}$ eq & TRACI | BEES \\
\hline IR & Ionizing radiation & ionizing radiation & Bq C-14 eq $\mid$ DALY $\mid$ man. Sv/kBq & $\begin{array}{l}\text { IMPACT2002+ | EI99 | CML | ReCiPe | } \\
\text { IMPACTworld+ }\end{array}$ \\
\hline \multirow[t]{3}{*}{ HT } & \multirow[t]{3}{*}{ Human toxicity } & human health & $\mathrm{C} 7 \mathrm{H} 8 \mathrm{eq}$ & BEES 2.0 \\
\hline & & criteria air pollutants & microDALYs & BEES 2.0 \\
\hline & & human toxicity potential & $\begin{array}{l}\mathrm{kg} 1,4-\mathrm{DCBeq}|2,4 \mathrm{Deq}| \\
\text { chloroethylene eq. }|\mathrm{m} 3| \text { cases } \mid \\
\text { CTU }\end{array}$ & $\begin{array}{l}\text { IMPACT2002+ | TRACI | CML | EDIP | ReCiPe } \\
\quad \text { | ILCD | IMPACTworld+ }\end{array}$ \\
\hline \multirow[t]{2}{*}{ CA } & \multirow{2}{*}{$\begin{array}{l}\text { Carcinogenic } \\
\text { effects }\end{array}$} & carcinogenics & kg benzene | PAH eq. | kg C2H3Cl eq & TRACI | EI99 | EI95 | IMPACT2002+ \\
\hline & & noncarcinogenics & $\mathrm{kg}$ toluene $\mid \mathrm{kg} \mathrm{C} 2 \mathrm{H} 3 \mathrm{Cl}$ eq & TRACI | IMPACT2002+ \\
\hline \multirow[t]{9}{*}{ BD } & \multirow{9}{*}{$\begin{array}{l}\text { Biodiversity and } \\
\text { land use }\end{array}$} & land use & & EI99 \\
\hline & & land occupation & $\begin{array}{l}\text { m2org.arable } \mid \mathrm{m} 2 \text { occupation or } \\
\text { transformation }\end{array}$ & IMPACT2002+ | ReCiPe \\
\hline & & habitat alteration & $T \& E$ count & BEES 2.0 \\
\hline & & biodiversity & ha eq. & IMPACTworld+ \\
\hline & & erosion resistance potential & $\mathrm{kg} / \mathrm{m}^{2} \mid$ ton $/ \mathrm{ha} / \mathrm{y}$ & ILCD | IMPACTworld+ \\
\hline & & $\begin{array}{l}\text { mechanical filtration } \\
\text { potential }\end{array}$ & $\mathrm{m}^{3} / \mathrm{m}^{2} \mid \mathrm{cm} / \mathrm{d}$ & ILCD | IMPACTworld+ \\
\hline & & groundwater replenishment & $\mathrm{m}^{3} / \mathrm{m}^{2}$ & ILCD \\
\hline & & biotic production potential & $\mathrm{kg} / \mathrm{m}^{2} \mid \mathrm{tC} / \mathrm{ha} / \mathrm{y}$ & ILCD | IMPACTworld+ \\
\hline & & & $\mathrm{mm} / \mathrm{y}$ & IMPACTworld+ \\
\hline
\end{tabular}


Table 9 (continued)

\begin{tabular}{llll}
\hline Acronym Category & Impact category & Unit & LCIA method \\
\hline & $\begin{array}{l}\text { freshwater recharge } \\
\text { potential } \\
\text { chemical filtration potential }\end{array}$ & & \\
& $\mathrm{cmol} / \mathrm{kg}$ soil & IMPACTworld+ \\
& solid waste & $\mathrm{kg} \mid$ volume to landfill & BEES \\
& heavy metals & $\mathrm{Pb}$ eq. & EI95 \\
& environmental load Unit & ELU & EPS \\
& pesticides & active ingr. & EI95 \\
\hline
\end{tabular}

Acknowledgements Open access funding provided by University of Graz.

Funding This research was conducted within the K-ProjectWoodC.A.R. - Computer Aided Research which is funded within thescope of COMET-Competence Centers for Excellent Technologies byBMVIT, BMDW, and the Austrian federal states of Styria and Tyrolunder the Project Number 861421 . The program COMET is managed by the Austrian Research Promotion Agency (Österreichische Forschungsförderungsgesellschaft, FFG).

\section{References}

Agyekum EO, Fortuin KPJ, van der Harst E (2017) Environmental and social life cycle assessment of bamboo bicycle frames made in Ghana. J Clean Prod 143:1069-1080

Akhshik M, Panthapulakkal S, Tjong J, Sain M (2017) Life cycle assessment and cost analysis of hybrid fiber-reinforced engine beauty cover in comparison with glass fiber-reinforced counterpart. Environ Impact Assess Rev 65:111-117

Aleisa E, Al-Jarallah R (2018) A triple bottom line evaluation of solid waste management strategies: a case study for an arid Gulf State, Kuwait. Int J Life Cycle Assess 23(7):1460-1475

Allwood JM, Ashby MF, Gutowski TG, Worrell E (2011) Material efficiency: a white paper. Resour Conserv Recycl 55:362-381

Alves C, Ferrão PMC, Silva AJ, Reis LG, Freitas M, Rodrigues LB, Alves DE (2010) Ecodesign of automotive components making use of natural jute fiber composites. J Clean Prod 18:313-327

Andrews E, Lesage P, Benoît C, Parent J, Norris G, Revéret J-P (2009) Life cycle attribute assessment. J Ind Ecol 13(4):565-578

Aparcana S, Salhofer S (2013) Application of a methodology for the social life cycle assessment of recycling systems in low income countries: three Peruvian case studies. Int J Life Cycle Assess 18(5):1116-1128

Arcese G, Lucchetti MC, Massa I (2017) Modeling social life cycle assessment framework for the Italian wine sector. J Clean Prod 140: $1027-1036$

Arcese G, Lucchetti MC, Massa I, Valente C (2018) State of the art in SLCA: integrating literature review and automatic text analysis. Int J Life Cycle Assess 23:394-405

Arcese G, Lucchetti M, Merli R (2013) Social life cycle assessment as a management tool: methodology for application in tourism. Sustain 5(8):3275-3287

Arvidsson R, Baumann H, Hildenbrand J (2015) On the scientific justification of the use of working hours, child labour and property rights in social life cycle assessment: three topical reviews. Int J Life Cycle Assess 20:161-173

Asada R, Cardellini G, Mair-Bauernfeind C, Wenger J, Haas V (2020) Effective bioeconomy? A MRIO-based socioeconomic and environmental impact assessment of generic sectoral innovations. Technol Forecast Soc Chang 153:119946
Baumann H, Arvidsson R, Tong H, Wang Y (2013) Does the production of an airbag injure more people than the airbag saves in traffic? J Ind Ecol 17:517-527

Benoit C, Norris GA, Valdivia S, Ciroth A, Moberg A, Bos U, Prakash S, Ugaya C, Beck T (2010) The guidelines for social life cycle assessment of products: just in time! Int J Life Cycle Assess 15:156-163

Benoit-Norris C, Cavan DA, Norris G (2012) Identifying social impacts in product supply chains: overview and application of the social hotspot database. Sustain 4:1946-1965

Boland CS, de Kleine R, Keoleian GA, Lee EC, Kim HC, Wallington TJ (2016) Life cycle impacts of natural fiber composites for automotive applications: effects of renewable energy content and lightweighting. J Ind Ecol 20(1):179-189

Bolin CA, Smith ST (2011a) Life cycle assessment of ACQ-treated lumber with comparison to wood plastic composite decking. J Clean Prod 19(6-7):620-629

Bolin CA, Smith ST (2011b) Life cycle assessment of borate-treated lumber with comparison to galvanized steel framing. J Clean Prod 19(6-7):630-639

Bolin CA, Smith ST (2011c) Life cycle assessment of pentachlorophenoltreated wooden utility poles with comparisons to steel and concrete utility poles. Renew Sustain Energ Rev 15:2475-2486

Brandão M, Levasseur A, Kirschbaum MUF, Weidema BP, Cowie AL, Jørgensen SV, Hauschild MZ, Pennington DW, Chomkhamsri K (2013) Key issues and options in accounting for carbon sequestration and temporary storage in life cycle assessment and carbon footprinting. Int J Life Cycle Assess 18:230-240

Brooke AL (2008) Ford model T: the car that put the world on wheels. Motorbooks, St. Paul

Cambria D, Pierangeli D (2012) Application of a life cycle assessment to walnut tree (Juglans regia L.) high quality wood production: a case study in southern Italy. J Clean Prod 23(1):37-46

Chen W, Holden NM (2017) Social life cycle assessment of average Irish dairy farm. Int J Life Cycle Assess 22:1459-1472

Cherubini F, Raugei M, Ulgiati S (2008) LCA of magnesium production. Technological overview and worldwide estimation of environmental burdens. Resour Conserv Recycl 52:1093-1100

Cobut A, Blanchet P, Beauregard R (2015) The environmental footprint of interior wood doors in non-residential buildings - part 1: life cycle assessment. J Clean Prod 109:232-246

Cordella M, Hidalgo C (2016) Analysis of key environmental areas in the design and labelling of furniture products: application of a screening approach based on a literature review of LCA studies. Sustain Prod Consum 8:64-77

Corona B, Bozhilova-Kisheva KP, Olsen SI, San Miguel G (2017) Social Life Cycle Assessment of a Concentrated Solar Power Plant in Spain: A Methodological Proposal. J Ind Ecol 21(6):1566-1577

Dalmijn WL, de Jong TPR (2007) The development of vehicle recycling in Europe: sorting, shredding, and separation. JOM 59:52-56

Das S (2000) The life-cycle impacts of aluminum body-in-white automotive material. JOM 52(8):41-44 
Das S (2011) Life cycle assessment of carbon fiber-reinforced polymer composites. Int J Life Cycle Ass 16:268-282

Das S (2014) Life cycle energy and environmental assessment of aluminum-intensive vehicle design. SAE Int J Mater Manuf 7

Delogu M, Zanchi L, Dattilo CA, Pierini M (2017) Innovative composites and hybrid materials for electric vehicles lightweight design in a sustainability perspective. Mater Today Commun 13:192-209

de Luca AI, Falcone G, Stillitano T, Iofrida N, Strano A, Gulisano G (2018) Evaluation of sustainable innovations in olive growing systems: a life cycle sustainability Assessment case study in southern Italy. J Clean Prod 171:1187-1202

Diener DL, Tillman A-M (2016) Scrapping steel components for recycling-Isn't that good enough?: seeking improvements in automotive component end-of-life. Resour Conserv Recycl 110:48-60

Ding N, Gao F, Wang Z, Yang J (2016) Life cycle energy and greenhouse gas emissions of automobiles using aluminum in China. J Ind Ecol 20(4):818-827

do Carmo BBT, Margni M, Baptiste P (2017) Addressing uncertain scoring and weighting factors in social life cycle assessment. Int $\mathrm{J}$ Life Cycle Assess 22(10):1609-1617

Dong YH, Ng ST (2015) A social life cycle assessment model for building construction in Hong Kong. Int J Life Cycle Ass 20:1166-1180

Dong YH, Ng ST (2016) A modeling framework to evaluate sustainability of building construction based on LCSA. Int J Life Cycle Ass 21: 555-568

dos Santos MFN, Battistelle RAG, Bezerra BS, Varum HSA (2014) Comparative study of the life cycle assessment of particleboards made of residues from sugarcane bagasse (Saccharum spp.) and pine wood shavings (Pinus elliottii). J Clean Prod 64:345-355

dos Santos TB, Evrard D, Brissaud D, Mathieux F, Arruda JR (2014) Use of recycled natural fibres in industrial products: a comparative LCA case study on acoustic components in the Brazilian automotive sector. Resour Conserv Recycl 84:1-14

Dreyer LC, Niemann AL, Hauschild MZ (2003) Comparison of three different LCIA methods: EDIP97, CML2001 and eco-indicator 99: does it matter which one you choose? Int J Life Cycle Assess 8:191-200

Dreyer L, Hauschild M, Schierbeck J (2006) A framework for social life cycle impact assessment (10 pp). Int J Life Cycle Assess 11:88-97

Dreyer LC, Hauschild MZ, Schierbeck J (2010a) Characterisation of social impacts in LCA. Int J Life Cycle Assess 15:247-259

Dreyer LC, Hauschild MZ, Schierbeck J (2010b) Characterisation of social impacts in LCA. Part 2: implementation in six company case studies. Int J Life Cycle Assess 15:385-402

Du C, Ugaya C, Freire F, Dias LC, Clift R (2019) Enriching the results of screening social life cycle assessment using content analysis: a case study of sugarcane in Brazil. Int J Life Cycle Assess 24(4):781-793

Dubreuil A, Bushi L, Das S, Tharumarajah A, Gong X (2012) A comparative life cycle assessment of magnesium front end autoparts: a revision to 2010-01-0275. SAE TECH PAP.

Duflou JR, de MJ, Verpoest I, Dewulf W (2009) Environmental impact analysis of composite use in car manufacturing. CIRP Annals 58(1): 9-12

EC (2010a) Commission decision of 10 June 2010 on guidelines for the calculation of land carbon stocks for the purpose of annex $\mathrm{V}$ to Directive 2009/28/EC: 2010/335/EU EC. Official Journal of the European Union

EC (2010b) ILCD handbook: framework and requirements for life cycle impact assessment, Luxembourg

EC (2010c) ILCD Handbook: General guide for Life Cycle Assessment. Detailed guidance, 1st edn, Luxembourg

Engert S, Rauter R, Baumgartner RJ (2016) Exploring the integration of corporate sustainability into strategic management: a literature review. J Clean Prod 112:2833-2850

EPA US (2016) Tool for Reduction and Assessment of Chemicals and Other Environmental Impacts (TRACI). https://www.epa.gov/ chemical-research/tool-reduction-and-assessment-chemicals-andother-environmental-impacts-traci. Accessed 8 April 2019

Ermolaeva NS, Castro MBG, Kandachar PV (2004) Materials selection for an automotive structure by integrating structural optimization with environmental impact assessment. Mater Design 25(8):689-698

European Commission (ed) (2000) End-of Life Vehicles: DIRECTIVE 2000/53/EC

European Commission (ed) (2014) Emission performance standards for new passenger cars: REGULATION (EC) No 443/2009

Fan L, Pang B, Zhang Y, Zhang X, Sun Y, Wang Y (2018) Evaluation for social and humanity demand on green residential districts in China based on SLCA. Int J Life Cycle Assess 23(3):640-650

Fink A (2020) Conducting research literature reviews: from the internet to paper, 5th edn. Sage Publications, Inc., Thousand Oaks

Finnveden G, Hauschild MZ, Ekvall T, Guinée J, Heijungs R, Hellweg S, Koehler A, Pennington D, Suh S (2009) Recent developments in life cycle assessment. J Environ Manag 91:1-21

Fitch PE, Cooper JS (2003) Life cycle energy analysis as a method for material selection. In: Gupta SK (ed) Proceedings of the 2002 Asme Design Engineering Technical Conferences and Computers and Information in Engineering Conference. American Society of Mechanical Engineers, New York, NY, pp 95-102

Franze J, Ciroth A (2011) A comparison of cut roses from Ecuador and the Netherlands. Int J Life Cycle Assess 16(4):366-379

Frenette CD, Bulle C, Beauregard R, Salenikovich A, Derome D (2010) Using life cycle assessment to derive an environmental index for light-frame wood wall assemblies. Build Environ 45:2111-2122

Frühwald A, Wegener G (1993) Energiekreislauf Holz- ein Vorbild für die Zukunft. HOLZ- Erzeugung und Verwendung-Ein Kreislauf der Natur. 15. Dreiländer-Holztagung in Garmisch-Partenkirchen, pp 49-60

García-Durañona L, Farreny R, Navarro P, Boschmonart-Rives J (2016) Life Cycle Assessment of a coniferous wood supply chain for pallet production in Catalonia, Spain. J Celan Prod 137:178-188

Garrido SR (2017) Social life-cycle assessment: an introduction. In: Abraham M (ed) Encyclopedia of sustainable technologies. Elsevier Science, Saint Louis, pp 253-265

Garrido SR, Parent J, Beaulieu L, Revéret J-P (2018) A literature review of type I SLCA - making the logic underlying methodological choices explicit. Int J Life Cycle Assess 23:432-444

Gasol CM, Farreny R, Gabarrell X, Rieradevall J (2008) Life cycle assessment comparison among different reuse intensities for industrial wooden containers. Int J Life Cycle Assess 13(5):421-431

Geyer R (2008) Parametric Assessment of Climate Change Impacts of Automotive Material Substitution. Environ Sci Technol 42(18): 6973-6979

Ghaderi H, Moini A, Pishvaee MS (2018) A multi-objective robust possibilistic programming approach to sustainable switchgrassbased bioethanol supply chain network design. J Clean Prod 179: 368-406

González-García S, Feijoo G, Widsten P, Kandelbauer A, ZikulnigRusch E, Moreira MT (2009) Environmental performance assessment of hardboard manufacture. Int J Life Cycle Ass 14:456-466

González-García S, Gasol CM, Lozano RG, Moreira MT, Gabarrell X, Rieradevall i Pons J, Feijoo G (2011a) Assessing the global warming potential of wooden products from the furniture sector to improve their ecodesign. Sci Total Environ 410-411:16-25

González-García S, Silva FJ, Moreira MT, Pascual RC, Lozano RG, Gabarrell X, i Pons JR, Feijoo G (2011b) Combined application of LCA and eco-design for the sustainable production of wood boxes for wine bottles storage. Int J Life Cycle Assess 16(3):224-237

González-García S, Lozano RG, Estévez JC, Pascual RC, Moreira MT, Gabarrell X, i Pons JR, Feijoo G (2012) Environmental assessment and improvement alternatives of a ventilated wooden wall from LCA and DfE perspective. Int J Life Cycle Assess 17:432-443 
Guinée JB, Heijungs R, Huppes G, Zamagni A, Masoni P, Buonamici R, Ekvall T, Rydberg T (2011) Life cycle assessment: past, present, and future. Environ Sci Technol 45:90-96

Hakamada M, Furuta T, Chino Y, Chen Y, Kusuda H, Mabuchi M (2007) Life cycle inventory study on magnesium alloy substitution in vehicles. Energy 32(8):1352-1360

Hannouf M, Assefa G (2018) Subcategory assessment method for social life cycle assessment: a case study of high-density polyethylene production in Alberta, Canada. Int J Life Cycle Assess 23(1):116-132

Hardwick AP, Outteridge T (2016) Vehicle lightweighting through the use of molybdenum-bearing advanced high-strength steels (AHSS). Int J Life Cycle Assess 21(11):1616-1623

Hasenheit M, Gerdes H, Kiresiewa Z, Beekman V (2016) Summary report on the social, economic and environmental impacts of the bioeconomy. http://www.bio-step.eu/fileadmin/BioSTEP/Bio documents/BioSTEP D2.2 Impacts of the bioeconomy.pdf. Accessed 14 Feb 2019

Hauschild MZ, Goedkoop M, Guinée J, Heijungs R, Huijbregts M, Jolliet O, Margni M, de Schryver A, Humbert S, Laurent A, Sala S, Pant R (2013) Identifying best existing practice for characterization modeling in life cycle impact assessment. Int J Life Cycle Assess 18:683-697

Hesser F (2015) Environmental advantage by choice: Ex-ante LCA for a new Kraft pulp fibre reinforced polypropylene composite in comparison to reference materials. Compos Part B-Eng 79:197-203

Hesser F, Wohner B, Meints T, Stern T, Windsperger A (2016) Integration of LCA in R\&D by applying the concept of payback period: case study of a modified multilayer wood parquet. Int $\mathrm{J}$ Life Cycle Assess 22:307-316

Höglmeier K, Weber-Blaschke G, Richter K (2014) Utilization of recovered wood in cascades versus utilization of primary wood - a comparison with life cycle assessment using system expansion. Int J Life Cycle Assess 19(10):1755-1766

Höglmeier K, Weber-Blaschke G, Richter K (2016) Evaluation of wood cascading. In: Dewulf J, Meester S, Alvarenga RAF (eds) Sustainability assessment of renewables-based products: methods and case studies. Wiley, Chichester

Hossain MU, Poon CS, Dong YH, Lo IMC, Cheng JCP (2018) Development of social sustainability assessment method and a comparative case study on assessing recycled construction materials. Int J Life Cycle Assess 23(8):1654-1674

Hosseinijou SA, Mansour S, Shirazi MA (2014) Social life cycle assessment for material selection: a case study of building materials. Int J Life Cycle Ass 19:620-645

Hottle T, Caffrey C, McDonald J, Dodder R (2017) Critical factors affecting life cycle assessments of material choice for vehicle mass reduction. Transp Res D Transp Environ 56:241-257

Hsieh H-F, Shannon S (2005) Three approaches to qualitative content analysis. Qual Health Res 15:1277-1288

Hu S, Guan X, Guo M, Wang J (2018) Environmental load of solid wood floor production from larch grown at different planting densities based on a life cycle assessment. J For Res 29(5):1443-1448

Huijbregts MAJ, Rombouts LJA, Hellweg S, Frischknecht R, Hendriks AJ, van de Meent D, Ragas AMJ, Reijnders L, Struijs J (2006) Is cumulative fossil energy demand a useful Indicator for the environmental performance of products? Environ Sci Technol 40:641-648

Huijbregts MAJ, Hellweg S, Frischknecht R, Hendriks HWM, Hungerbühler K, Hendriks AJ (2010) Cumulative energy demand as predictor for the environmental burden of commodity production. Environ Sci Technol 44:2189-2196

Hunkeler D (2006) Societal LCA methodology and case study (12 pp). Int J Life Cycle Assess 11:371-382

IPCC (2006) Guidelines for national greenhouse gas inventories: volume 4. Agriculture, forestry, and other land use, Japan

ISO (2006a) 14040:2006(E): Environmental management - Life cycle assessment - Principles and framework, 2nd edn, Switzerland
ISO (2006b) 14044:2006(E): Environmental management - Life cycle assessment - Requirements and guidelines

Jolliet O, Margni M, Charles R, Humbert S, Payet J, Rebitzer G, Rosenbaum R (2003) IMPACT 2002+: a new life cycle impact assessment methodology. Int J Life Cycle Assess 8:324-330

Jørgensen A (2013) Social LCA—a way ahead? Int J Life Cycle Assess 18:296-299

Karjalainen T, Asikainen A (1996) Greenhouse gas emissions from the use of primary energy in forest operations and long-distance transportation of timber in Finland. Forestry 69(3):215-228

Kim H-J, McMillan C, Keoleian GA, Skerlos SJ (2010) Greenhouse gas emissions payback for lightweighted vehicles using aluminum and high-strength steel. J Ind Ecol 14(6):929-946

Klein D, Wolf C, Schulz C, Weber-Blaschke G (2015) 20 years of life cycle assessment (LCA) in the forestry sector: state of the art and a methodical proposal for the LCA of forest production. Int J Life Cycle Assess 20:556-575

Klinglmair M, Sala S, Brandão M (2014) Assessing resource depletion in LCA: a review of methods and methodological issues. Int J Life Cycle Assess 19:580-592

Kloepffer W (2008) Life cycle sustainability assessment of products. Int J Life Cycle Assess 13:89-95

Koffler C (2014) Life cycle assessment of automotive lightweighting through polymers under US boundary conditions. Int J Life Cycle Assess 19(3):538-545

Koh LP (2007) Potential habitat and biodiversity losses from intensified biodiesel feedstock production. Conserv Biol 21:1373-1375

Koh LP, Ghazoul J (2008) Biofuels, biodiversity, and people: understanding the conflicts and finding opportunities. Biol Conserv 141:2450-2460

Kohl D, Link P, Böhm S (2016) Wood as a technical material for structural vehicle components. Procedia CIRP 40:557-561

Kolotzek C, Helbig C, Thorenz A, Reller A, Tuma A (2018) A companyoriented model for the assessment of raw material supply risks, environmental impact and social implications. J Clean Prod 176:566-580

Kühnen M, Hahn R (2017) Indicators in social life cycle assessment: a review of frameworks, theories, and empirical experience. J Ind Ecol 21:1547-1565

La Rosa AD, Recca G, Summerscales J, Latteri A, Cozzo G, Cicala G (2014) Bio-based versus traditional polymer composites. A life cycle assessment perspective. J Clean Prod 74:135-144

Laurent A-B, Gaboury S, Wells J-R, Bonfils S, Boucher J-F, Sylvie B, D'Amours S, Villeneuve C (2013) Cradle-to-gate life-cycle assessment of a glued-laminated wood product from quebec's boreal forest. Forest Prod J 63(5-6):190-198

Lee SG, Xu X (2004) A simplified life cycle assessment of re-usable and single-use bulk transit packaging. Packag Techn Sci 17(2):67-83

Lehmann A, Russi D, Bala A, Finkbeiner M, Fullana-i-Palmer P (2011) Integration of social aspects in decision support, based on life cycle thinking. Sustain 3(4):562-577

Lenzo P, Traverso M, Salomone R, Ioppolo G (2017) Social life cycle assessment in the textile sector: an Italian case study. SustainabilityBasel 9:2092

Lettner M, Solt P, Rößiger B, Pufky-Heinrich D, Jääskeläinen A-S, Schwarzbauer P, Hesser F (2018) From wood to resinidentifying sustainability levers through hotspotting lignin valorisation pathways. Sustain 10:2745

Levasseur A, Lesage P, Margni M, Brandão M, Samson R (2012) Assessing temporary carbon sequestration and storage projects through land use, land-use change and forestry: comparison of dynamic life cycle assessment with ton-year approaches. Clim Chang 115:759-776

Lippiat CB (2007) BEES 4.0: building for environmental and economic sustainability technical manual and user guide. NISTIR 7423. National Institute of Standards and Technology

Lippke B, Oneil E, Harrison R, Skog K, Gustavsson L, Sathre R (2011) Life cycle impacts of forest management and wood utilization on carbon mitigation: Knowns and unknowns. Carbon Manag 2:303-333 
Liu G, Müller DB (2012) Addressing sustainability in the aluminum industry: a critical review of life cycle assessments. J Clean Prod 35:108-117

Lu H, El Hanandeh A (2016) Life cycle assessment of ACQ-treated Veneer Based Composite (VBC) hollow utility poles from hardwood plantation mid-thinning. Sustain Prod Consum 5:36-50

Luz SM, Caldeira-Pires A, Ferrão PMC (2010) Environmental benefits of substituting talc by sugarcane bagasse fibers as reinforcement in polypropylene composites: Ecodesign and LCA as strategy for automotive components. Resour Conserv Recy 54:1135-1144

Mahalle L, Alemdar A, Mihai M, Legros N (2014) A cradle-to-gate life cycle assessment of wood fibre-reinforced polylactic acid (PLA) and polylactic acid/thermoplastic starch (PLA/TPS) biocomposites. Int J Life Cycle Assess 19(6):1305-1315

Mair S, Druckman A, Jackson T (2018) Investigating fairness in global supply chains: applying an extension of the living wage to the Western European clothing supply chain. Int J Life Cycle Ass 23: 1862-1873

Manik Y, Leahy J, Halog A (2013) Social life cycle assessment of palm oil biodiesel: a case study in Jambi Province of Indonesia. Int J Life Cycle Assess 18(7):1386-1392

Martínez-Blanco J, Lehmann A, Muñoz P, Antón A, Traverso M, Rieradevall J, Finkbeiner M (2014) Application challenges for the social life cycle assessment of fertilizers within life cycle sustainability assessment. J Clean Prod 69:34-48

Mattioda RA, Mazzi A, Canciglieri O, Scipioni A (2015) Determining the principal references of the social life cycle assessment of products. Int J Life Cycle Assess 20:1155-1165

Mayring P (2000) Qualitative Inhaltsanalyse. Grundlagen und Techniken, 7th edn. Deutscher Studien Verlag, Weinheim

Mayyas A, Qattawi A, Omar M, Shan D (2012a) Design for sustainability in automotive industry: a comprehensive review. Renew Sust Energ Rev 16:1845-1862

Mayyas AT, Qattawi A, Mayyas AR, Omar MA (2012b) Life cycle assessment-based selection for a sustainable lightweight body-inwhite design. Energy 39:412-425

McCormick K, Kautto N (2013) The bioeconomy in Europe: an overview. Sustainability 5:2589-2608

McKechnie J, Colombo S, Chen J, Mabee W, MacLean HL (2011) Forest bioenergy or forest carbon? Assessing trade-offs in greenhouse gas mitigation with wood-based fuels. Environ Sci Technol 45:789-795

Meredith J (1993) Theory building through conceptual methods. Int J Oper Prod Manag 13:3-11

Mirdar Harijani A, Mansour S, Karimi B, Lee C-G (2017) Multi-period sustainable and integrated recycling network for municipal solid waste - A case study in Tehran. J Clean Prod 151:96-108

Mohanty AK, Misra M, Drzal LT (2001) Surface modifications of natural fibers and performance of the resulting biocomposites: an overview. Compos Interface 8:313-343

Mohanty AK, Misra M, Drzal LT (2002) Sustainable bio-composites from renewable resources: opportunities and challenges in the green materials world. J Polym Environ 10:19-26

Nakano K, Ando K, Takigawa M, Hattori N (2018) Life cycle assessment of wood-based boards produced in Japan and impact of formaldehyde emissions during the use stage. Int J Life Cycle Assess 23(4): 957-969

Neuendorf KA (2017) The content analysis guidebook, 2nd edn. SAGE, Los Angeles, London, New Delhi, Washington, DC, Melbourne

Neugebauer S, Emara Y, Hellerström C, Finkbeiner M (2017) Calculation of fair wage potentials along products' life cycle Introduction of a new midpoint impact category for social life cycle assessment. J Clean Prod 143:1221-1232

Noda R, Kayo C, Yamanouchi M, Shibata N (2016) Life cycle greenhouse gas emission of wooden guardrails: a study in Nagano Prefecture. J Wood Sci 62(2):181-193

Omar MA (2011) The automotive body manufacturing systems and processes. Wiley, Chichester
Opher T, Shapira A, Friedler E (2018) A comparative social life cycle assessment of urban domestic water reuse alternatives. Int J Life Cycle Assess 23(6):1315-1330

Owsianiak M, Laurent A, Bjørn A, Hauschild MZ (2014) IMPACT 2002+, ReCiPe 2008 and ILCD's recommended practice for characterization modelling in life cycle impact assessment: a case studybased comparison. Int J Life Cycle Assess 19:1007-1021

Park J, Horvath L, Bush RJ (2018) Life cycle inventory analysis of the wood pallet repair process in the United States. J Ind Ecol 22(5): $1117-1126$

Pawelzik P, Carus M, Hotchkiss J, Narayan R, Selke S, Wellisch M, Weiss M, Wicke B, Patel MK (2013) Critical aspects in the life cycle assessment (LCA) of bio-based materials - reviewing methodologies and deriving recommendations. Resour Conserv Recycl 73:211-228

Pennington DW, Potting J, Finnveden G, Lindeijer E, Jolliet O, Rydberg T, Rebitzer G (2004) Life cycle assessment part 2: current impact assessment practice. Environ Int 30:721-739

Petersen AK, Solberg B (2002) Greenhouse gas emissions, life-cycle inventory and cost-efficiency of using laminated wood instead of steel construction. Case: beams at Gardermoen airport. Environ Sci Policy 5(2):169-182

Petersen AK, Solberg B (2004) Greenhouse gas emissions and costs over the life cycle of wood and alternative flooring materials. Clim Chang 64:143-167

Petersen AK, Solberg B (2005) Environmental and economic impacts of substitution between wood products and alternative materials: a review of micro-level analyses from Norway and Sweden. Forest Policy Econ 7:249-259

Petti L, Sanchez Ramirez PK, Traverso M, Ugaya CML (2018) An Italian tomato "Cuore di Bue" case study: challenges and benefits using subcategory assessment method for social life cycle assessment. Int J Life Cycle Assess 23(3):569-580

Petti L, Serreli M, Di Cesare S (2018) Systematic literature review in social life cycle assessment. Int J Life Cycle Assess 23:422-431

Phungrassami H, Usubharatana P (2015) Life cycle assessment and Ecoefficiency of Para-rubber wood production in Thailand. Pol J Environ Stud 24:2113-2126

Pizzirani S, McLaren SJ, Forster ME, Pohatu P, Porou TTW, Warmenhoven TA (2018) The distinctive recognition of culture within LCSA: realising the quadruple bottom line. Int J Life Cycle Assess 23:663-682

Pizzol M, Christensen P, Schmidt J, Thomsen M (2011) Impacts of "metals" on human health: a comparison between nine different methodologies for life cycle impact assessment (LCIA). J Clean Prod 19:646-656

Poulikidou S, Schneider C, Björklund A, Kazemahvazi S, Wennhage P, Zenkert D (2015) A material selection approach to evaluate material substitution for minimizing the life cycle environmental impact of vehicles. Mater Des 83:704-712

Prasara-A J, Gheewala SH (2018) Applying social life cycle assessment in the thai sugar industry: challenges from the field. J Clean Prod 172:335-346

Puri P, Compston P, Pantano V (2009) Life cycle assessment of Australian automotive door skins. Int J Life Cycle Assess 14(5): 420-428

Rafiaani P, Kuppens T, van Dael M, Azadi H, Lebailly P, van Passel S (2018) Social sustainability assessments in the biobased economy: towards a systemic approach. Renew Sust Energ Rev 82:1839-1853

Raugei M, Morrey D, Hutchinson A, Winfield P (2015) A coherent life cycle assessment of a range of lightweighting strategies for compact vehicles. J Clean Prod 108:1168-1176

Reuter B (2016) Assessment of sustainability issues for the selection of materials and technologies during product design: a case study of lithium-ion batteries for electric vehicles. Int J Interact Des Manuf 10(3):217-227 
Ribeiro C, Ferreira JV, Partidário P (2007) Life cycle assessment of a multi-material car component. Int J Life Cycle Assess 12:336-345

Rivela B, Hospido A, Moreira T, Feijoo G (2006) Life cycle inventory of particleboard: a case study in the wood sector (8 pp). Int J Life Cycle Assess 11(2): 106-113

Rivela B, Moreira MT, Feijoo G (2007) Life cycle inventory of medium density fibreboard. Int J Life Cycle Assess 12(3):143-150

Rosenbaum RK (2018) Chapter 40: overview of existing LCIA methods: annex to chapter 10. In: Hauschild MZ, Rosenbaum RK, Olsen SI (eds) Life cycle assessment: theory and practice, 1st edn. Springer Nature, Basel

Rosenbaum RK, Hauschild MZ, Boulay A-M, Fantke P, Laurent A, Núñez M, Vieira M (2018) Life cycle impact assessment. In: Hauschild MZ, Rosenbaum RK, Olsen SI (eds) Life cycle assessment: theory and practice, 1st edn. Springer Nature, Basel, pp 167270

Salazar J, Husted BW, Biehl M (2012) Thoughts on the evaluation of corporate social performance through projects. J Bus Ethics 105:175-186

Sanchez Ramirez PK, Petti L, Ugaya CML (2014) Subcategory assessment method for social LCA: a first application on the wine sector. In: Salomone R, Saija G (eds) Pathways to environmental sustainability, vol 1, 1st edn. Springer International Publishing Switzerland, Cham, pp 107-116

Schau EM, Traverso M, Finkbeiner M (2012) Life cycle approach to sustainability assessment: a case study of remanufactured alternators. J Remanuf 2(1)

Siebert A, Bezama A, O'Keeffe S, Thrän D (2018a) Social life cycle assessment indices and indicators to monitor the social implications of wood-based products. J Clean Prod

Siebert A, Bezama A, O'Keeffe S, Thrän D (2018b) Social life cycle assessment: in pursuit of a framework for assessing wood-based products from bioeconomy regions in Germany. Int $\mathrm{J}$ Life Cycle Assess 23:651-662

SimaPro (2019) SimaPro Database Manual: Methods libary. https:// si mapro.com/w p-content/uploads/2019/02/ DatabaseManualMethods.pdf. Accessed 4 July 2019

Singh RK, Gupta U (2018) Social life cycle assessment in Indian steel sector: a case study. Int J Life Cycle Assess 23(4):921-939

Sommerhuber PF, Wenker JL, Rüter S, Krause A (2017) Life cycle assessment of wood-plastic composites: Analysing alternative materials and identifying an environmental sound end-of-life option. Resour Conserv Recy 117:235-248

Song YS, Youn JR, Gutowski TG (2009) Life cycle energy analysis of fiber-reinforced composites. Compos Part A-Appl Sci Manuf 40(8): $1257-1265$

Souza A, Watanabe MDB, Cavalett O, Ugaya CML, Bonomi A (2018) Social life cycle assessment of first and second-generation ethanol production technologies in Brazil. Int J Life Cycle Assess 23(3): 617-628

Spitzley DV, Dietz BA, Keoleian GA (2006) Life-cycle assessment of office furniture products: final report on the study of three Steelcase office furniture products: Airtouch table, Garland desk, and Siento chair. Report no. CSS06-11, Ann Arbor, Michigan

Subramanian V, Semenzin E, Zabeo A, Saling P, Ligthart T, van Harmelen T, Malsch I, Hristozov D, Marcomini A (2018) Assessing the social impacts of nanoenabled products through the life cycle: the case of nano-enabled biocidal paint. Int J Life Cycle Assess 23(2):348-356

Sun X, Liu J, Lu B, Zhang P, Zhao M (2017) Life cycle assessment-based selection of a sustainable lightweight automotive engine hood design. Int J Life Cycle Assess 22(9):1373-1383

Sureau S, Mazijn B, Garrido SR, Achten WMJ (2018) Social life-cycle assessment frameworks: a review of criteria and indicators proposed to assess social and socioeconomic impacts. Int J Life Cycle Assess 23:904-920
Sutterlüty A, Hesser F, Schwarzbauer P, Schuster KC, Windsperger A, Stern T (2017) A delphi approach to understanding varying expert viewpoints in sustainability communication: the case of water footprints of bio-based fiber resources. J Ind Ecol 21(2):412-422

Teah HY, Onuki M (2017) Support Phosphorus Recycling Policy with Social Life Cycle Assessment: A Case of Japan. Sustain 9(7):1223

Tharumarajah A, Koltun P (2007) Is there an environmental advantage of using magnesium components for light-weighting cars? J Clean Prod 15(11-12):1007-1013

Touceda MI, Neila FJ, Degrez M (2018) Modeling socioeconomic pathways to assess sustainability: a tailored development for housing retrofit. Int J Life Cycle Assess 23:710-725

Traverso M, Bell L, Saling P, Fontes J (2018) Towards social life cycle assessment: a quantitative product social impact assessment. Int $\mathrm{J}$ Life Cycle Assess 23:597-606

Traverso M, Asdrubali F, Francia A, Finkbeiner M (2012) Towards life cycle sustainability assessment: an implementation to photovoltaic modules. Int J Life Cycle Assess 17(8):1068-1079

Tsalis T, Avramidou A, Nikolaou IE (2017) A social LCA framework to assess the corporate social profile of companies: Insights from a case study. J Clean Prod 164:1665-1676

Tseng Y-C, Lee Y-M, Liao S-J (2017) An integrated assessment framework of offshore wind power projects applying equator principles and social life cycle assessment. Sustain 9(10):1822

Udo de Haes H, Jolliet O, Finnveden G, Hauschild M, Krewitt W, Müller-Wenk R (1999) Best available practice regarding impact categories and category indicators in life cycle impact assessment. Int J Life Cycle Assess 4:167-174

Udo de Haes HA, Finnveden G, Goedkoop M, Hertwich E, Hofstetter P, Klöpffer W, Krewitt W, Lindeijer E (2002) Life cycle impact assessment: striving towards best practice. In: Hauschild MZ, Udo de Haes HA, Finnveden G, Goedkoop M, Hauschild M, Hertwich E, Hofstetter P, Klöpffer W (eds) Proceedings. SETAC Press, Pensacola

UNEP/SETAC (2009) Guidelines for social life cycle assessment of products. UNEP DTIE, Sustainable Consumption and Production Branch, Paris

United Nations (2014) Country classification, Data sources, country classifications and aggregation methodology: World Economic Situation and Prospects 2014. http://www.un.org/en/development/ desa/policy/wesp/wesp current/2014wesp country classification. pdf. Accessed 22 Feb 2018

van Acker K, Verpoest I, de MJ, Duflou J-R, Dewulf W (2009a) Lightweight materials for the automotive: Environmental impact analysis of the use of composites. Rev Metall-Paris 106:541-546

van der Voet E, van Oers L, Nikolic I (2003) Dematerialisation: not just a matter of weight. Leiden University, Leiden

VERBI GmbH (2019) MAXQDA: The Art of Data Analysis. https:// www.maxqda.de/. Accessed 18 April 2019

Wang S-W, Hsu C-W, Hu AH (2017) An analytical framework for social life cycle impact assessment - part 2: case study of labor impacts in an IC packaging company. Int J Life Cycle Assess 22(5):784-797

Wenker JL, Achenbach H, Diederichs SK, Rüter S (2016) Life cycle assessment of wooden interior doors in germany: a sector-representative approach for a complex wooden product according to EN 15804 methodology. J Ind Ecol 20(4):730-742

Witik RA, Payet J, Michaud V, Ludwig C, Månson J-AE (2011) Assessing the life cycle costs and environmental performance of lightweight materials in automobile applications. Compos Part AAppl S 42:1694-1709

Wohlin C (2014) Guidelines for snowballing in systematic literature studies and a replication in software engineering. In: Shepperd M, Hall T, Myrtveit I (eds) Proceedings of the 18th international conference on evaluation and assessment in software engineering. ACM, New York, pp 1-10

Wötzel K, Wirth R, Flake M (1999) Life cycle studies on hemp fibre reinforced components and ABS for automotive parts. Angew Makromol Chem 272(1):121-127 
Wulf C, Zapp P, Schreiber A, Marx J, Schlör H (2017) Lessons learned from a life cycle sustainability assessment of rare earth permanent magnets. J Ind Ecol 21(6):1578-1590

Xu X, Jayaraman K, Morin C, Pecqueux N (2008) Life cycle assessment of wood-fibre-reinforced polypropylene composites. J Mater Process Tech 198(1-3):168-177

Zah R, Hischier R, Leão AL, Braun I (2007) Curauá fibers in the automobile industry - a sustainability assessment. J Clean Prod 15(1112): $1032-1040$

Zamani B, Sandin G, Svanström M, Peters GM (2018) Hotspot identification in the clothing industry using social life cycle assessmentopportunities and challenges of input-output modelling. Int J Life Cycle Assess 23(3):536-546
Zimek M, Schober A, Mair C, Baumgartner RJ, Stern T, Füllsack M (2019) The third wave of LCA as the "decade of consolidation". Sustain 11:3283

Zimmer K, Fröhling M, Breun P, Schultmann F (2017) Assessing social risks of global supply chains: a quantitative analytical approach and its application to supplier selection in the German automotive industry. J Clean Prod 149:96-109

Publisher's note Springer Nature remains neutral with regard to jurisdictional claims in published maps and institutional affiliations. 